\title{
أساليب التفكير المفضلة لدى طلبة الدراسات العليا في جامعة إقليم سبأ اليمنية وعلاقتها ببعض المفضلة لمتلغير المراسات المليات
}

Preferred Thinking Styles of Graduate Students at Sheba Region University and their

Relationship to Certain Variables

$$
\text { د. محمد احمد علي قبقب(1) }
$$

\section{Dr. Mohammed Ahmed Ali Qubqub}




\section{ملخص الدراسة}

هدفت الدراسة إلى الكشف عن أساليب التفكير المفضَّلة لدى طلبة الدراسات العليا في جامعة إقليم سبأ

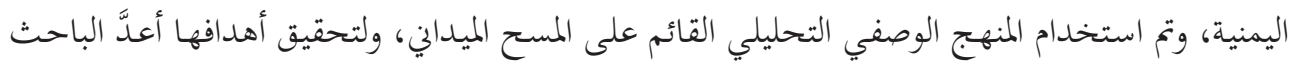

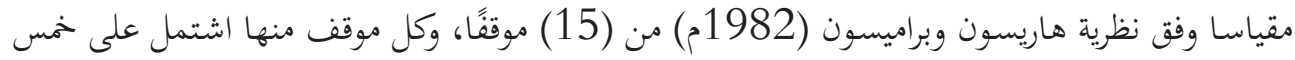
فقرات؛ لتقيس كل فقرة أحد أساليب التفكير الخمسة (المثالي، والواقعي، والعملي، والتحليلي، والتركيبي)

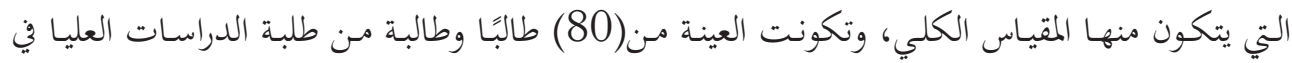

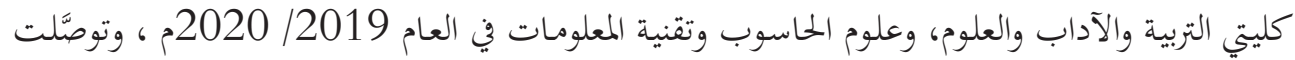
الدراسة إلى عدة نتائج؛ من أهمها أنَّ ترتيب أسلوب التفكير الواقعي حصل على ولى المرتبة الأولى في تقديرات الطلبة عن مدى تفضيلاتمم لأساليب التفكير، يليه أسلوب التفكير(التحليلي، فالعملي، ثم المثالي، وأخيرًا

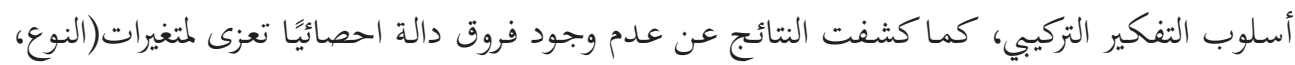
والكلية، والقسم الأكاديمي) بشكل عام. وتضمنت الدراسة عددًا من الاستنتاجات والتوصيات والمقترحات. الكلمات المفتاحية:أساليب التفكير، الدراسات العليا، جامعة إقليم سبأ. 
أساليب التفكير المفضلة لدى طلبة الدراسات العلياِِِ جامعة إقليم سبأ اليمنيد

د. محمد أحمدل على قبقب

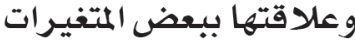

\section{Abstrac}

The study aimed at revealing the preferred thinking styles of graduate students at Sheba Region University. The descriptive analytic approach based on field surveys was followed in the study. To achieve the study objectives, the researcher prepared a scale of (15) domains according to the theory of Harrison and Bramson where each domain included (5) items. Each one of these items measured one of the five thinking styles (idealist, realist, pragmatist, analyst, and synthesist). The validity and reliability of the scale were verified by the known scientifically psychometric methods. The sample of the study consisted of (80) graduate students in the Faculty of Education, Arts and Sciences and the Faculty of Computer Science and Information Technology in the academic year of 2019/2020. The study concluded that the realistic thinking style ranks first in the students' estimates of their preferences for thinking styles, followed by the analytical, practical, idealistic, and synthetic thinking styles respectively. The results also revealed that there are no statistically significant differences attributed to the variables of gender, college, and academic department.

Keywords: thinking styles, graduate studies, Sheba Region University

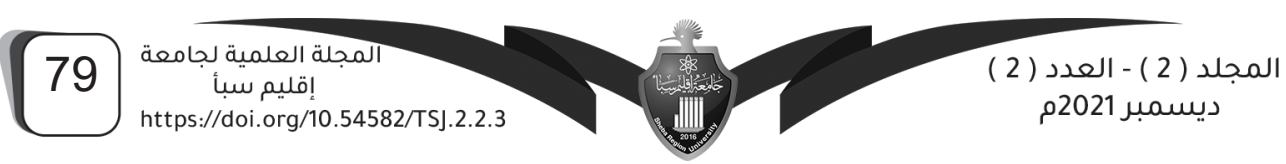




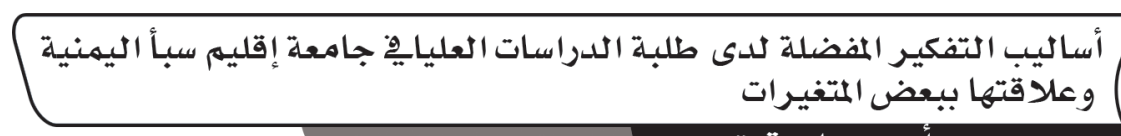

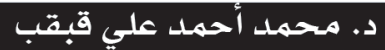

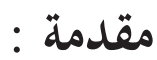

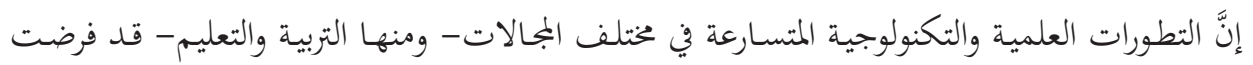

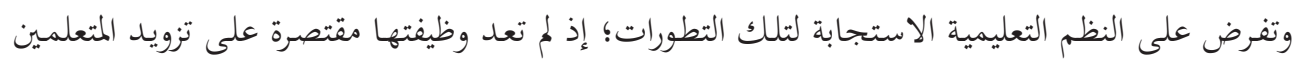

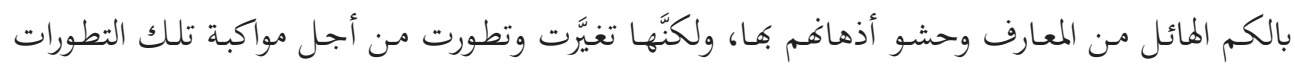

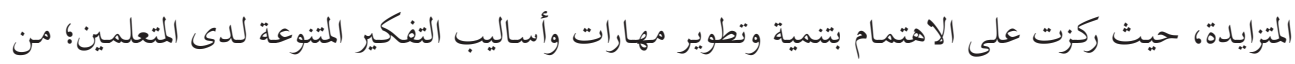

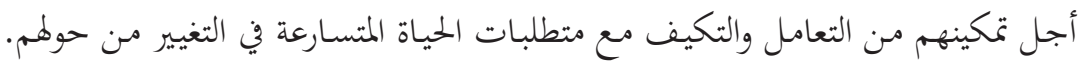

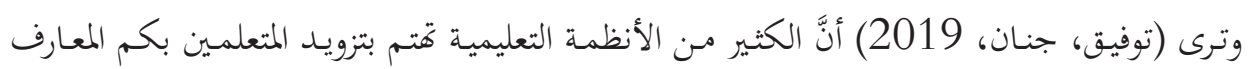

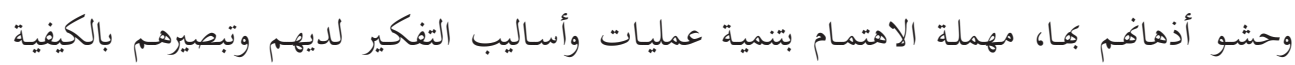

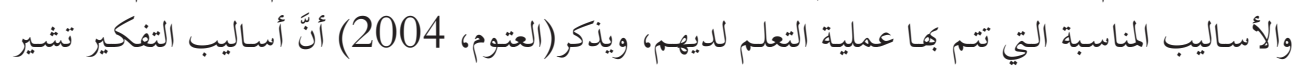

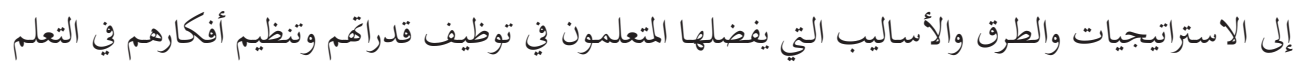

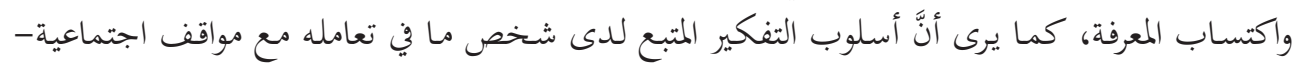

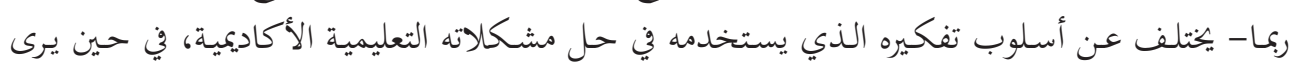

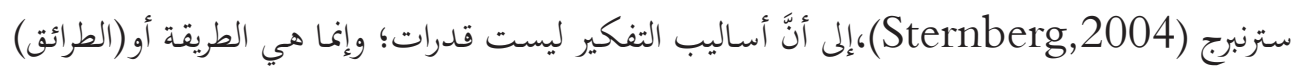

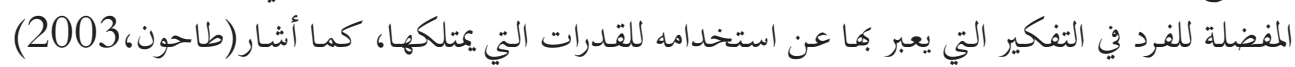

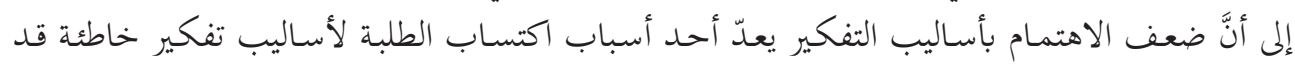

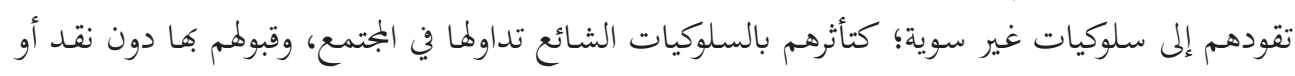

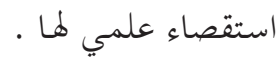

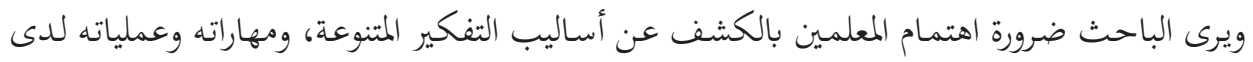

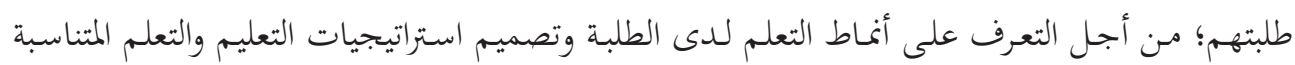

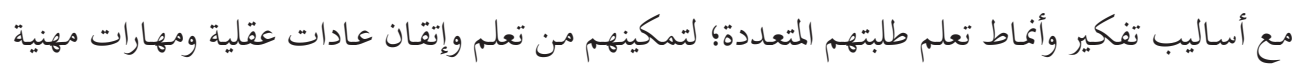

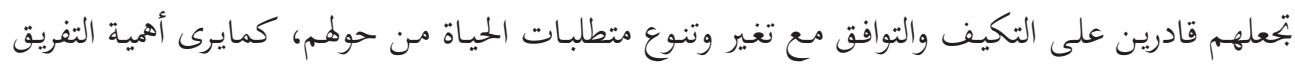

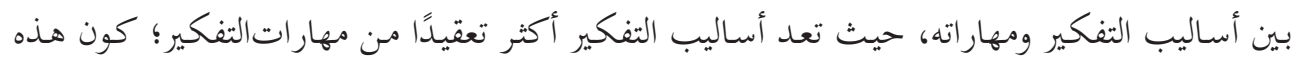

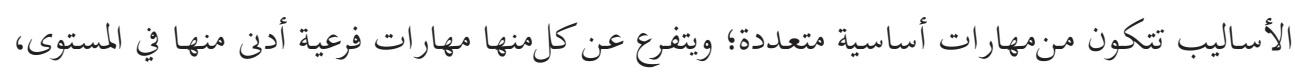

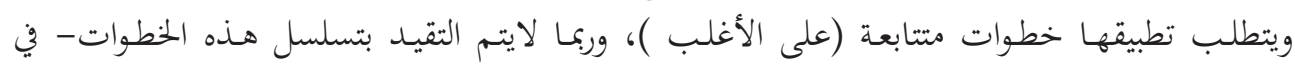

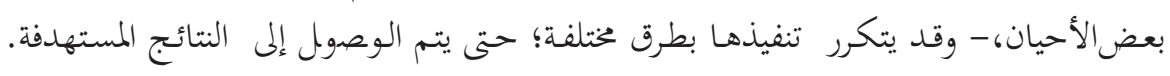

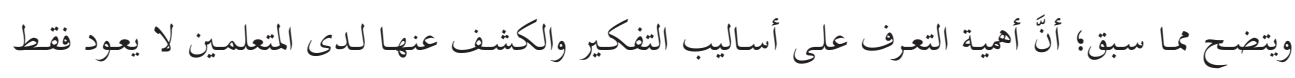

المجلد ( 2 ) - العدد ( 2 ( 2021 ) ديسمبر 2021م

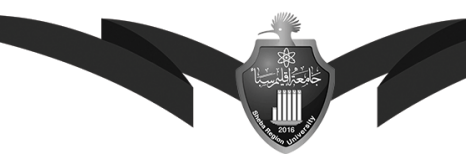




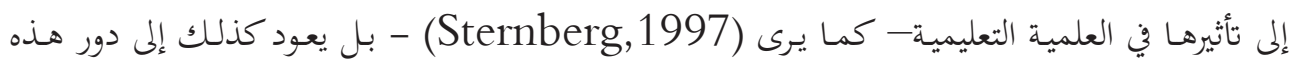

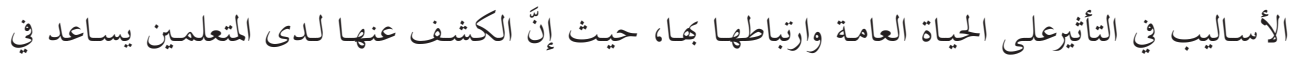

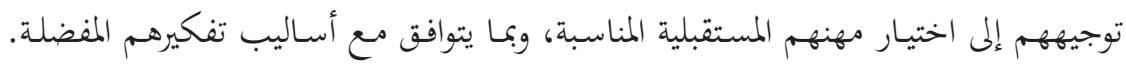

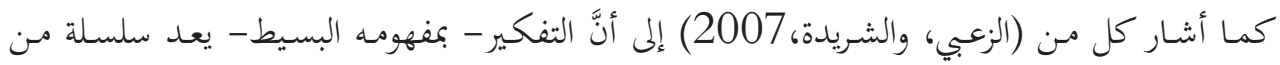

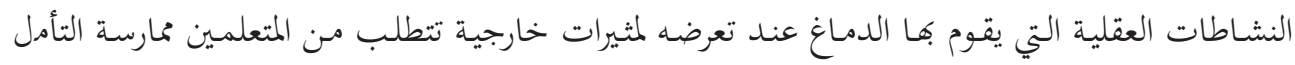

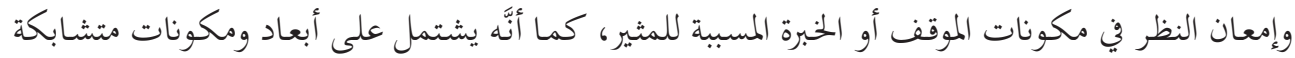

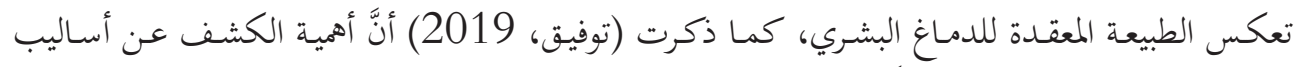

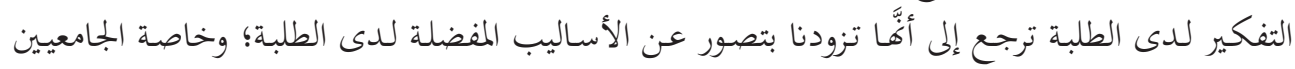

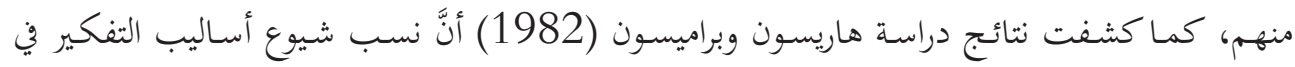

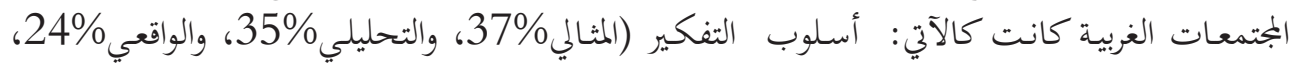

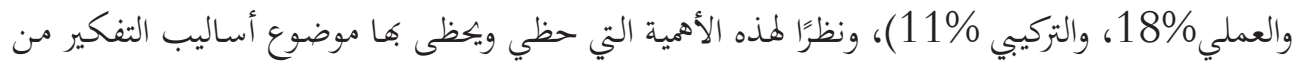

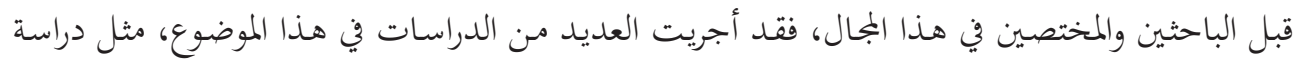

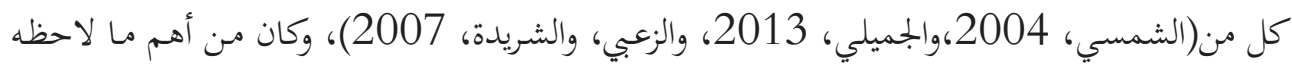

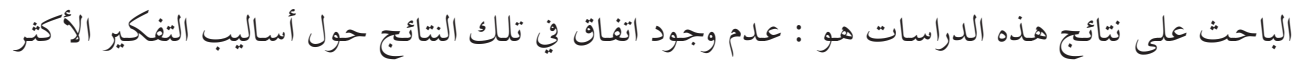

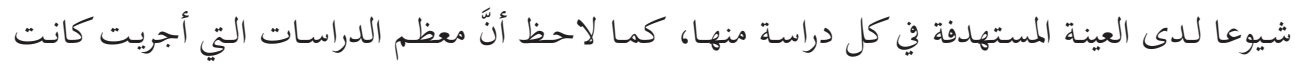

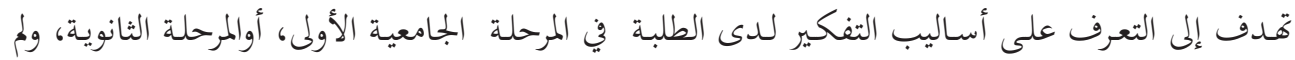

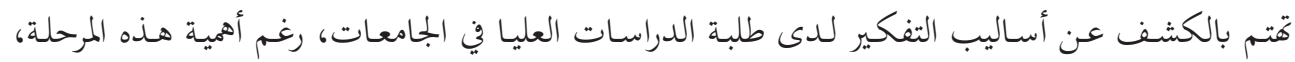

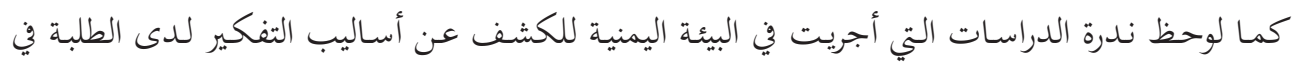

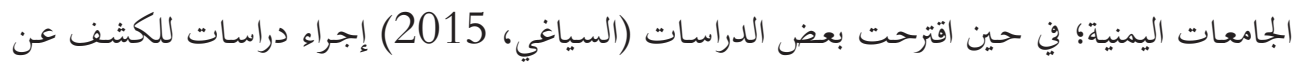

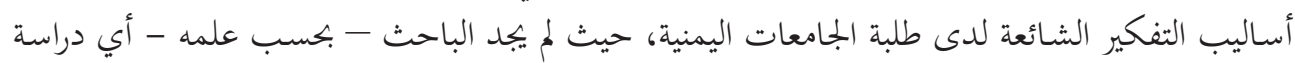

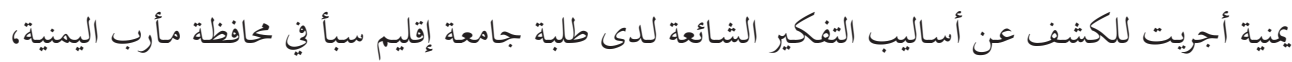

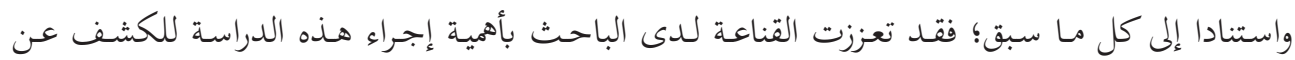

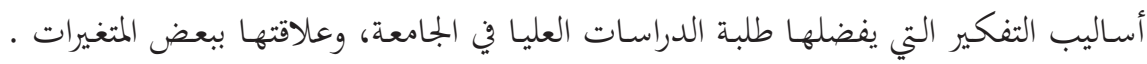

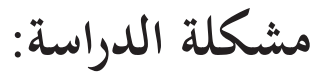

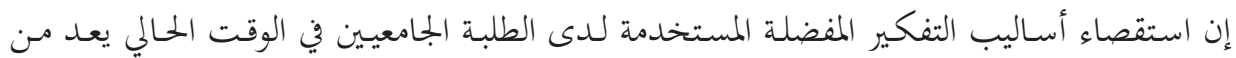

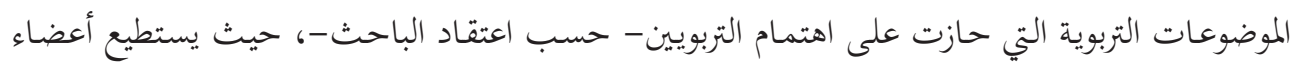

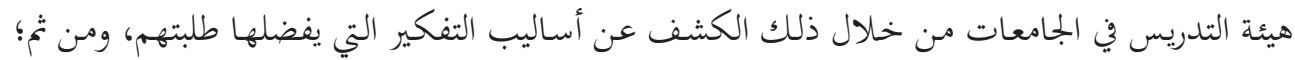




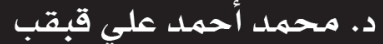

يمكنهم معرفة أسـاليب تعلمهمه، واختيـار الاستراتيجيات والأنشطة التدريسية المناسبة لتحقيق الأهـداف

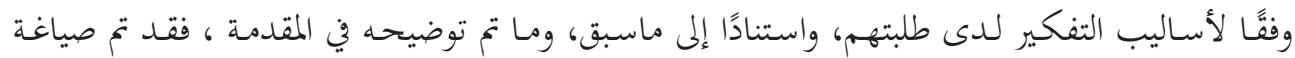
مشكلة الدراسة في السؤال الرئيس الآتي:

ما أساليب التفكير المفضلة لدى طلبة الدراسات العليا في جامعة إقليم سبأ اليمنية وما علاقتها ببعض المتغيرات؟

وتفرع من هذا السؤال الرئيس الأسئلة الفرعية الآتية:

ما مدى شيوع أساليب التفكير المفضلة لدى طلبة الدراسات العليا في جامعة إقليم سبأ اليمنية؟ هل توجد فروق ذات دلالة إحصائية (0,05) في تقديرات الطلبة لأساليب التفكير المفضلة لديهم تعزى

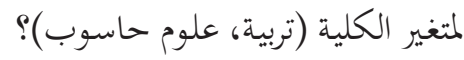

هل توجد فروق ذات دلالة إحصائية (0,05) في تقديرات الطلبة لأساليب التفكير المفضلة لديهم تعزى

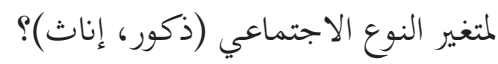

هل توجد فروق ذات دلالة إحصائية (0,05) في تقديرات الطلبة لأساليب التفكير المفضلة لديهم تعزى لمتغير القسم الأكاديمي (علمي، إنساني)؟ أهداف الدراسة: تسعى الدراسة إلى تحقيق الأهداف الآتية: التعرف على مـدى شيوع أسـاليب التفكير المفضلة لدى طلبة الدراسات العليا في جامعة إقليم سبأ اليمنيـة.

الكشف عن دلالة الفروق الإحصائية عند مستوى دلالة (0,05) في تقديرات الطلبة عن مدى شيوع أساليب التفكير المفضلة لديهم، والتي قد تعزى لمتغيرات (الكلية، والنوع الإجتماعي، والقسم الأكاديمي). أهمية الدراسة:انبثقت أهمية الدراسة من أهمية موضوعها الذي تناولته وهو أساليب التفكير، والذي حظي

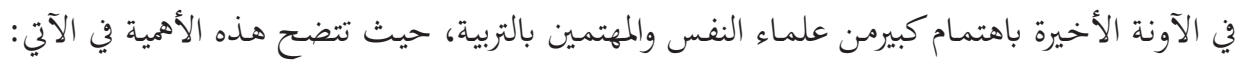
الأهمية النظرية: وتتمثل في نتائج الدراسة التي قد تشكل إضافة نوعية إلى المعرفة في مجال التفكير. الأهمية التطبيقية: وتتضح في الآتي: 
أساليب التفكير المفضلة لدى طلبة الدراسات العلياِِّ جامعة إقليم سبأ اليمنية

و وعلاقتها ببعض المتغير المضيرات ليت

\section{د. محمد أحمد علي قبقب}

إعداد مقياس لأساليب التفكير وفقًا لنظرية هاريسون وبراميسون (1982م)، والتأكد من صدقه وثباته

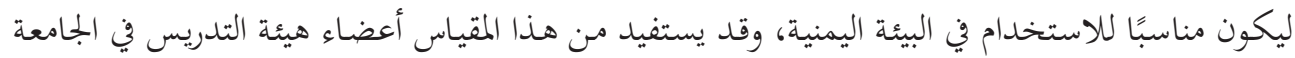

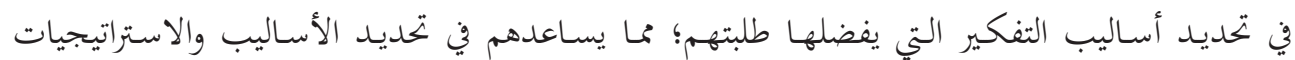

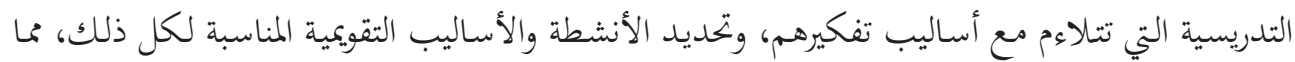

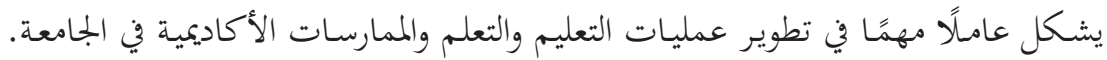

حدود الدراسة: اقتصرت حدود الدراسة على الحدود الآتية:

- حدود موضوعية: اقتصرت الدراسة على أساليب التفكير المفضلة لدى طلبة الدراسات العليا (السنة

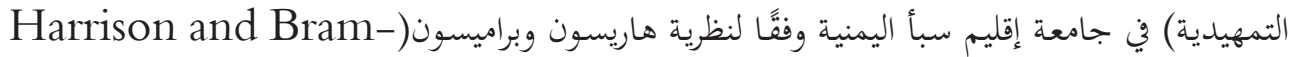
.(ison, 1982

- حدود مكانية: جامعة اقليم سبأ - محافظة مأرب. - حدود زمانية:الفصل الدراسي الثاني من 2019/ 2020م. - حدود بشرية: طلبة الدراسات العليا (السنة التمهيدية) في جامعة إقليم سبأ. فروض الدراسة: اشتملت الدراسة على الفروض الآتية: توجد فروق ذات دلالة إحصائية (0,05) في تقديرات الطلبة لأساليب التفكير المفضلة لديهم تعزى لمتغير الكلية (تربية، علوم حاسوب).

توجـد فروق ذات دلالة إحصائية (0,05) في تقديرات الطلبة لأسـاليب التفكير المفضلة لديهم تعزى لمتغير النوع (ذكور، إناث).

توجد فروق ذات دلالة إحصائية (0,05) في تقديرات الطلبة لأساليب التفكير المفضلة لديهم تعزى لمتغير القسم الأكاديمي (علمي، إنساني).

مصطلحات الدراسة: أورد الباحث تعريفات أكاديمية وإجرائية للمصطلحات الواردة في الدراسة؛ كالآي: التفكير:

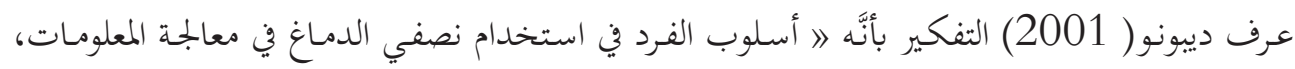

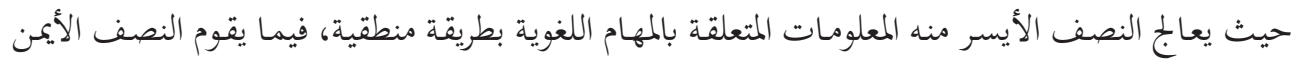




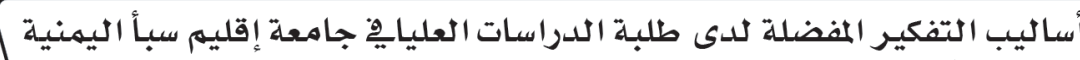
وعلاقتها ببعض الميركير المتغيـرات

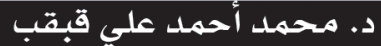

بمعالجة المعلومات المتعلقة بالادراك والضبط العضلي بطريقة تحليلية مجزأة).

ويعبرِف الباحث التفكير بأنَّه: ا الاكتشاف والتقصي المدروس والهادف للمواقف والأشياء والأحسداث

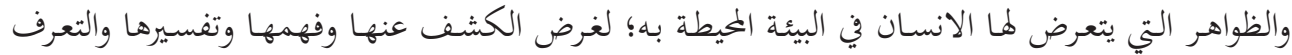
على العلاقات التي تربطها من أجل الاستفادة منها، أو دفع أضرارها.

أساليب التفكير: تعددت وتنوعت تعريفات المهتمين بالتربية العلمية لأساليب التفكير في الأدب التربوي، وقد يعود ذلك إلى تعدد وتنوع المدارس التي اهتمت بدراستها، حيث عرف كل من هاريسون وبراميسون (Harrison and Bramison,1982)

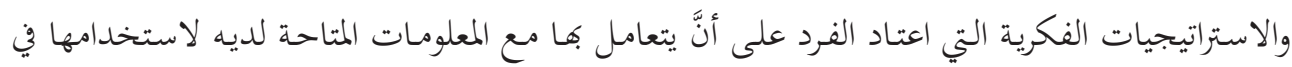

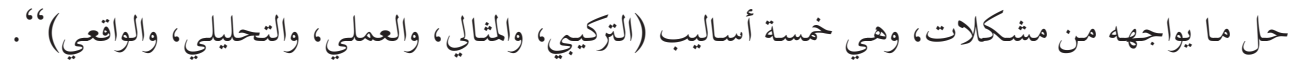
ويعرِفِ الباحث أساليب التفكير إجرائيًا بأهَّا : الدرجة التي حصل عليها الطالب من خلال أدائه على المقياس الكلي لأسـاليب التفكير، أومقاييسه الفرعية الخمسـة (التحليلي، والتركيبي، والواقعي، والمثالي، والعملي) وفقًا لنظرية هاريسون وبرامسون (Harrison and Bramison, 1982).

الدراسات العليا: هي برامج الماجستير الدراسية التي تقدمها جامعة إقليم سبأ لطلبتها في العام الجامعي 2019/ 2020م، وتشمل خمسة برامج هي : (الرياضيات، واللغة العربية، وعلوم القرآن، والمناهج وطرق التدريس، وعلوم الحاسوب) في كليتي التربية والعلوم، وعلوم الحاسوب وتكنولوجيا المعلومات. وتسات. جامعة اقليم سبأ: هي جامعة يمنية حكومية أنشئت بالقرار الجمهوري رقم(145)،وتاريخم 16/11/2016م، وتقع في مدينة مأرب، وتشـتمل على أربع كليات هي: (التربية والآداب والعلوم، وعلوم الحاسوب

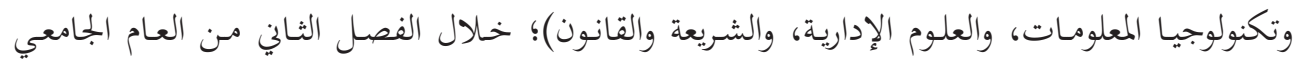
2020/2019

طلبة الدراسـات العليا: هـم الطلبـة المسـلون في الفصل الثاني مـ العام الجامعي 2019/2020 م -

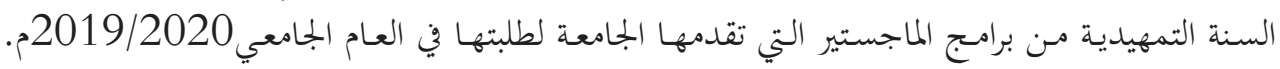

الإطار النظري: تنـاول الباحـث في هـذا الجحزء توضيحًا مختصـرًا لأهـم المفاهيمم الواردة في الدراسـة ،وهي: التفكير: عرَّف جريجورنكو وستيرنبرج Grigorenko \& Sternberg (1995) التفكيربأنه

المجلد (2 2 ) - العدد (2021 (20) ديسمبر 2021م

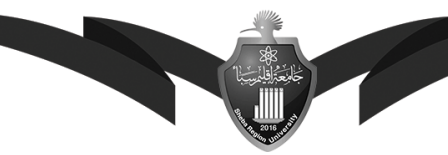


أساليب التفكير المفضلة لدى طلبة الدراسات العليابِّ جامعة إقليم سبأ اليمنية

وعلاقتها ببعض المتغيرات المضير التير

\section{د. محمد أحمد علي قبقب}

"عملية عقلية معرفية تؤثر بشكل مباشر في طريقة وكيفية تجهيز ومعالجة المعلومات والتمثيلات العقلية

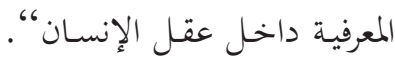

وعََفه نادي (2008) بأنَّهَ "نشاط ذهني يقوم به الإنسان عندما يتعرض لموقف ما، أومشكلة من أجل

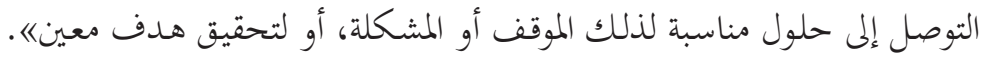

أساليب التفكير: تعددت وتنوعت تعريفات أساليب التتفكير الباحثين والمهتمين في التربية وعلم النفس، التسا،

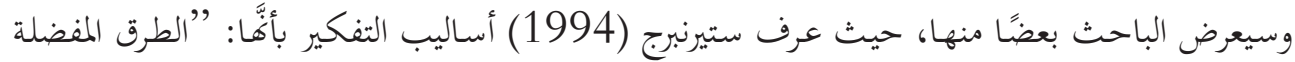

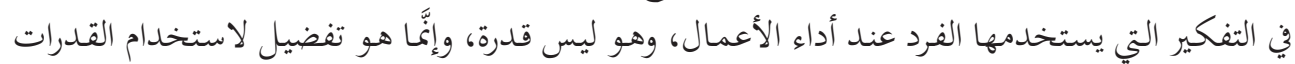
ويقع بين الشخصية والقدرات“،

نظرية هاريسون وبر امسون (Harrison and Bramison,1982: في ضوء الاهتمام المتزايد الذي

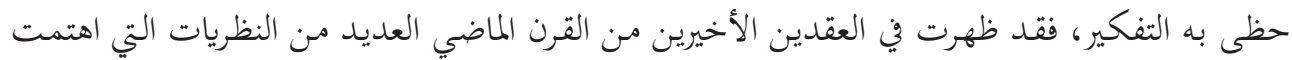

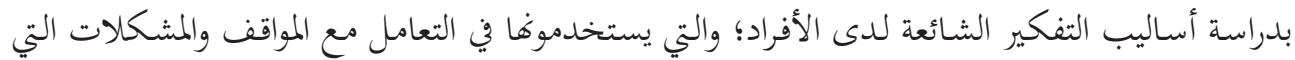

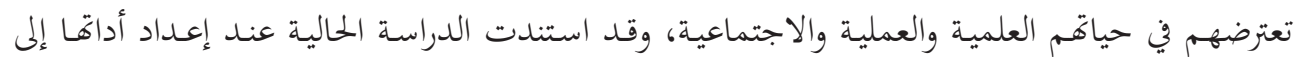

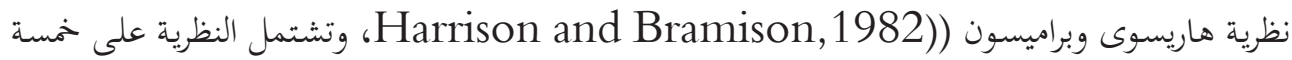
أساليب للتفكير، سوف يتناول الباحث كلاً منها بتوضيح مختصر لكل منها، وكما يأتي .

أسلوب التفكير التركيبي: أشار ( محمد، 2002) أنَّ الأفراد الذين يفضلون هذا الأسلوب من أساليب

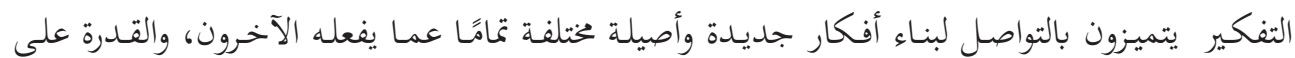

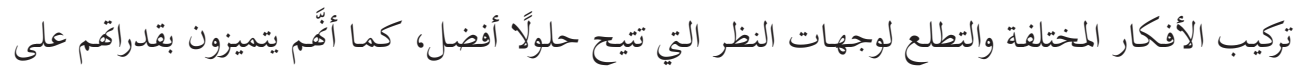

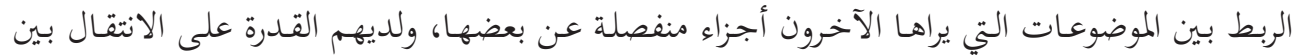
المجالات المتعددة بسهولة ويسر.

أسلوب التفكير المثالي: ذكر كل من ( علي، وصاحب، تئ2010) أنَّ الأفراد الذين يفضلون هذا الأسلوب

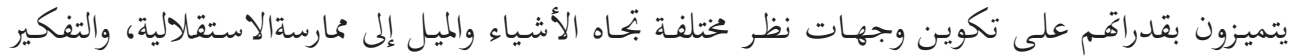

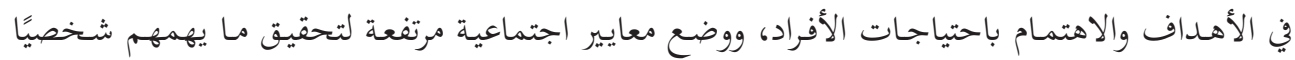

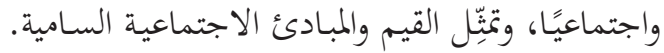

أسلوب التفكيرالعملي:أورد كل من ( الطراونة، والقضاة، 2014) بعض الصفات التي يتصف بها الأفراد

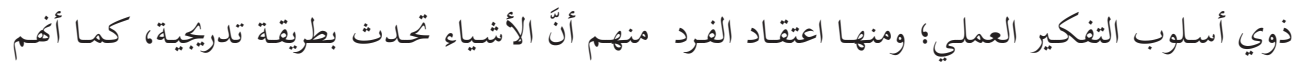

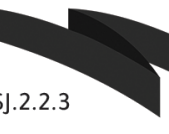




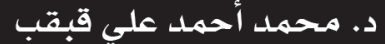

يميلون إلى البحث عن الحلول السريعة، والاهتمام بالجوانب الإجرائية في العمل، وحرية التجريب ، والقابلية للتكيف، كما أنَّ نظرقم للحقائق والقيم تعد نسبية، والتفوق في إيجاد طرائق جديدة لعمل الأشياء، والمهم

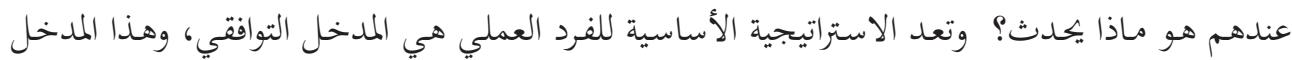

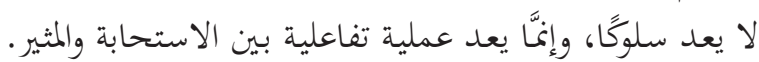

أسلوب التفكير التحليلي: ذكر (حبيب، 1996) أنَّ الأفراد الذين يفضلون هذا الأسلوب يتصفون

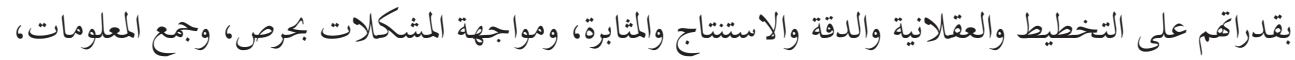
والاهتمام بتفاصيل الأشياء، ويفضلون التوجيه والارشاد، كما أنَّ الاستراتيجيات المفضلة للفرد التحليلي هي البحث عن أفضل الطرق المناسبة للحل.

أسلوب التفكير الواقعي: كر كل مـن ( الزعبي ، والشريدة، 2007) أنَّ الأفراد الذين يفضِّون هـذا

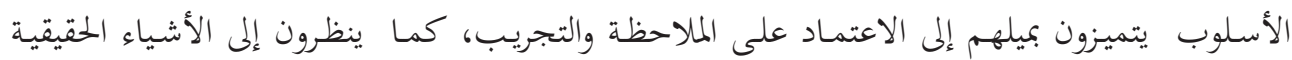

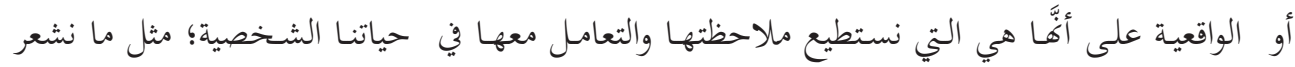

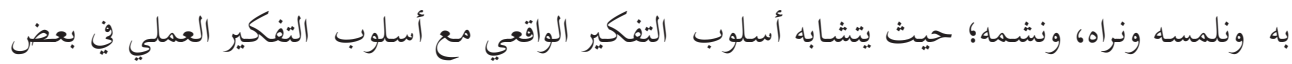
جوانبه ولكنهما يختلفـان في الفـروض والقيم و الاستراتيجيات المستخدمة في كل منهما على حلى حلدة. ويرى الباحث أنَّ التفكير يعد - في وقتنا الحالي - عاملاً من العوامل الأساسية في حياة الإنسان، فهو الذي يساعد على توجيه الحياة وتقدمها، كما يساعد على حل كثير من المشكالات وبتحنب كثير من الأخطار . ويرى(غالب،2000) أنَّ التفكير هو عملية عقلية معرفية وجدانية راقية تبنى على محصلة

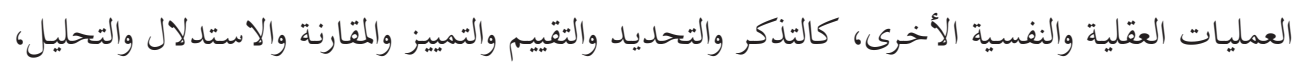

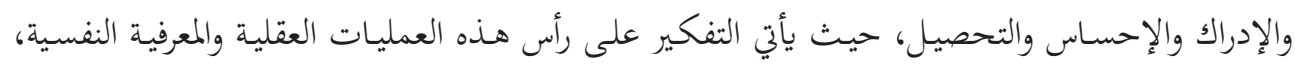

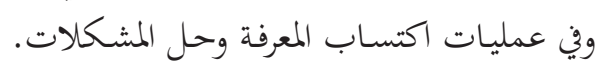

وأشار(Brayer, 1988) أنَّ المناهج الدراسية - خاصة الجامعية- لها دور كبير في تنمية وتطوير التفكير ومهاراته وعملياته المتعددة لدى الطلبة وتدريبهم على اكتسابه وتوظيفها في عمليات التعليم والتعلم وحل

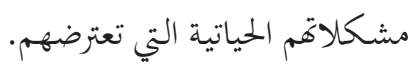

وفي حال عدم الاهتمام بالتفكير في التعليم الجامعي فسوف يبقى التعليم قائمًا على الحفظ والتلقين، وإذا لم تسع الجامعات في وضع الخطط والاستراتيجيات للانتقال والتطور في استحداث استراتيجيات حديثة

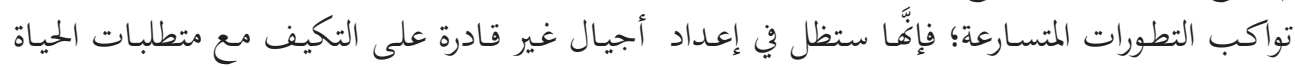

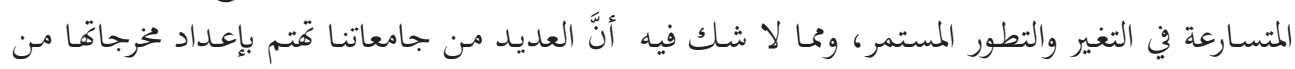

المجلد (2 2 ) - العدد (2021 (20) ديسمبر 2021م

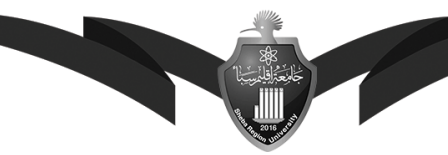


أساليب التفكير المفضلة لدى طلبة الدراسات العلياِِّ جامعة إقليم سبأ اليمنية

وعلاقتها ببعض المتغيرات المضير التير

\section{د. محمد أحهمد على قبقب}

خلال تزويدهم بالمعلومات والمعارف النظرية؛ دون الاهتمام الكافي بتنمية مهاراتم العقلية والتفكيرية التي تمكنهم من مواجهة المشكلات الحياتية بسهولة ويسر .

وقد أوضح كل من (Harrison \& Bramison, 1982) أنَّ تنوع أساليب التفكير لدى الأفراد

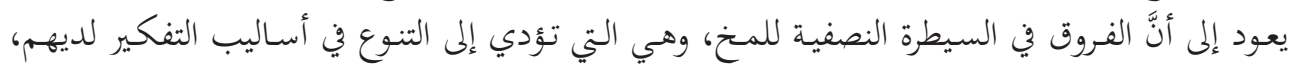

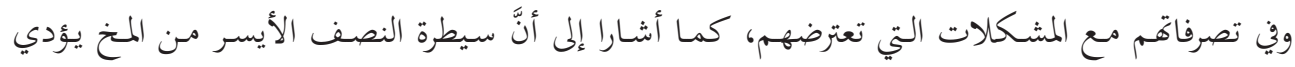

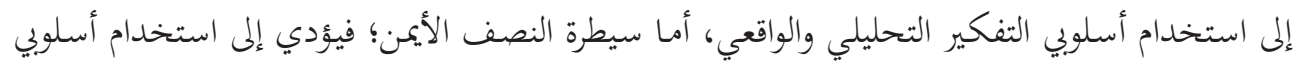

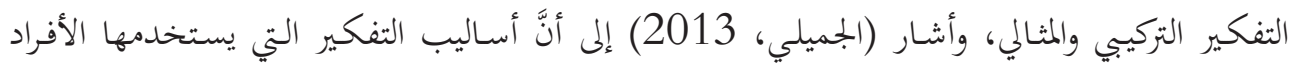

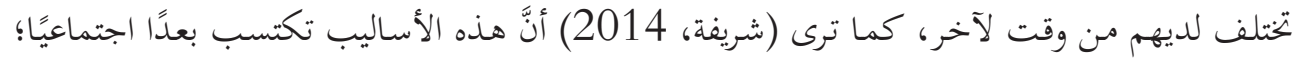

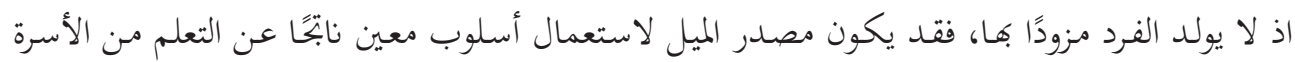

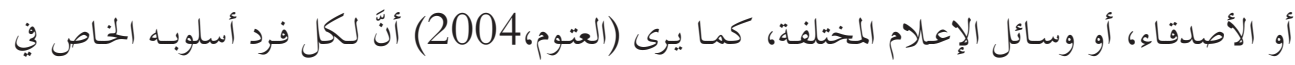

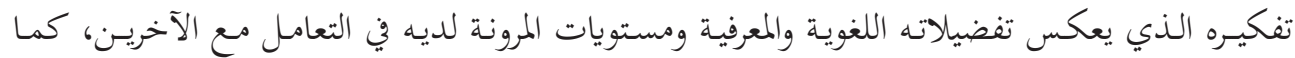

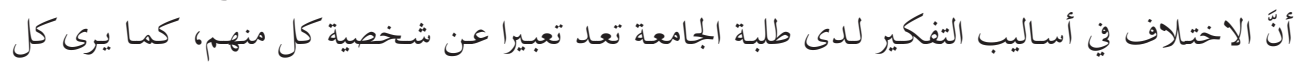

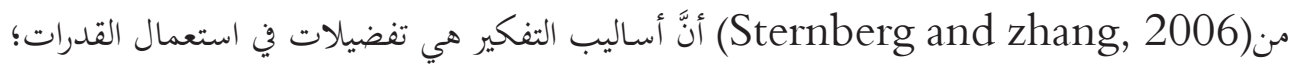

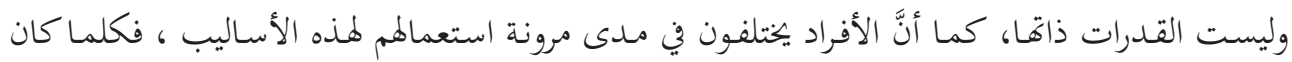

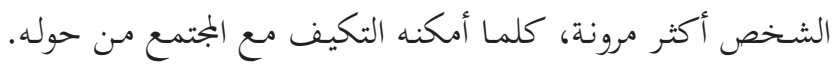

الدراسات السابقة: تناول الباحث في هذا الجزء عرض بعض الدراسات التي تناولت أساليب التفكير

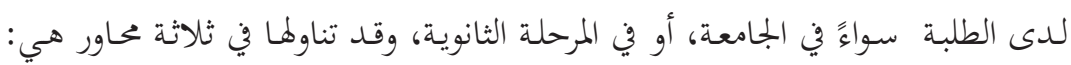

$$
\begin{aligned}
& \text { المحور الأول:دراسات محلية. } \\
& \text { المحور الثاني: دراسات عربية. } \\
& \text { المحور الثالث: دراسات أجنبية. } \\
& \text { أولًا :الدراسات العحلية: }
\end{aligned}
$$

دراسة السياغي (2015): هدفت إلى الكشف عن أساليب التفكير الشائعة لدى طلبة المرحلة الثانوية

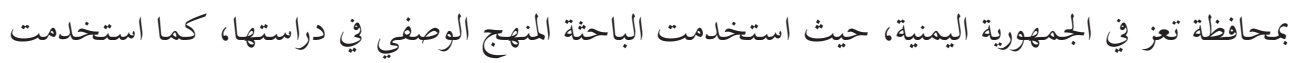

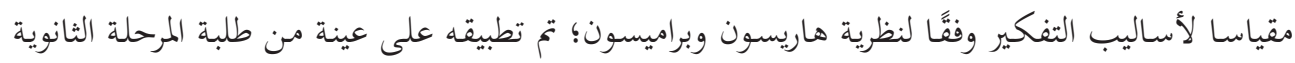

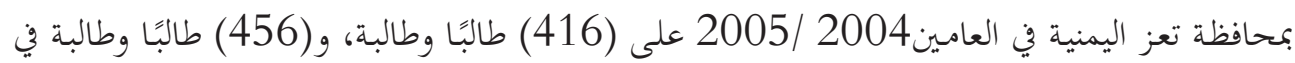
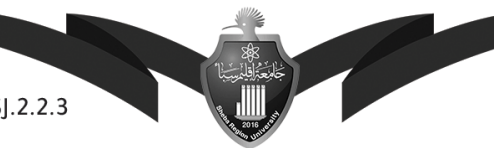

المجلد ( 2 ) - العدد ( 2 ) ديسمبر 2021م 


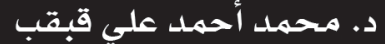

2008/2009،( وذلك من أجل المقارنة بين ترتيب أساليب التفكير بعد مرور أربعة أعوام من التطبيق

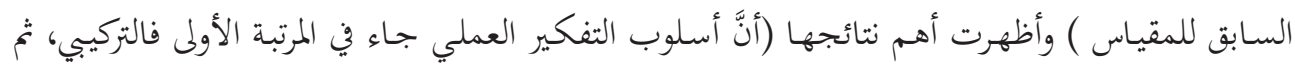

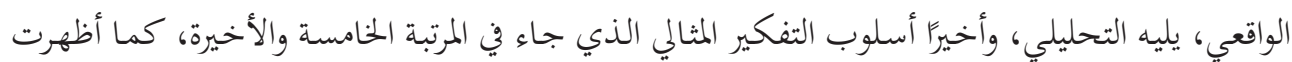

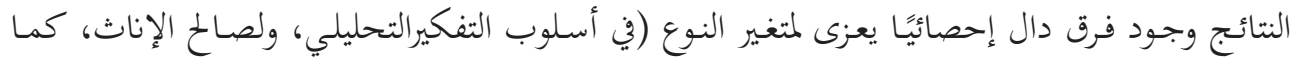

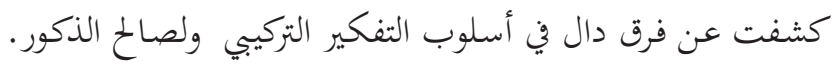

دراسة غالب (2000): هدفت إلى التعرف على أساليب التفكير الشائعة لدىى معلمي الثانوية قبل

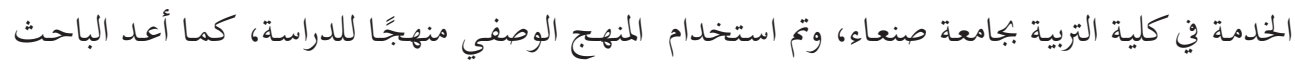

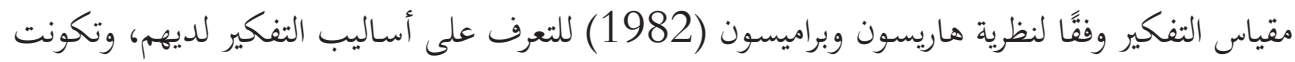

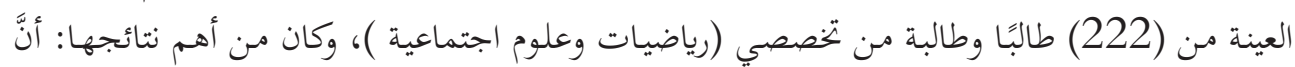

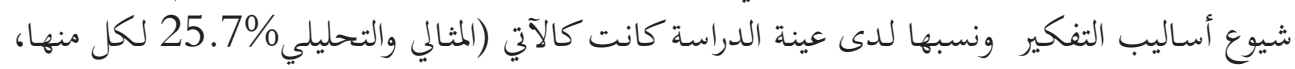

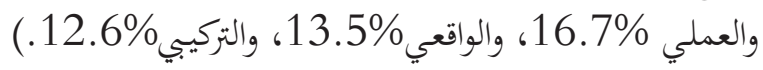

\section{ثانيًا: الدراسات العربية:}

دراسة (مرزوك، 2016): هدفت إلى التعرف على أساليب التفكير الشائعة لدى طلبة جامعة التها

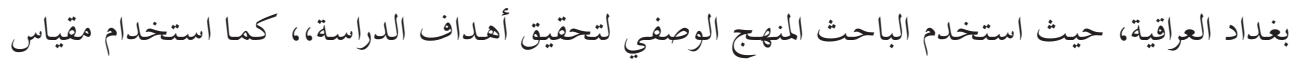

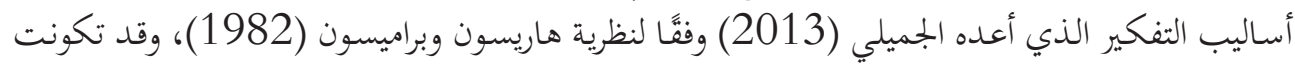

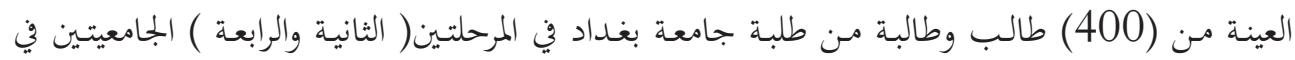

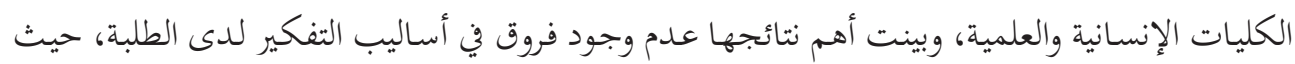

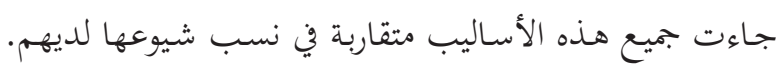

دراسة الطراونة، والقضاة (2014): هدفت إلى الكشف عن علاقة أساليب التفكير ومقاومة الإغراء

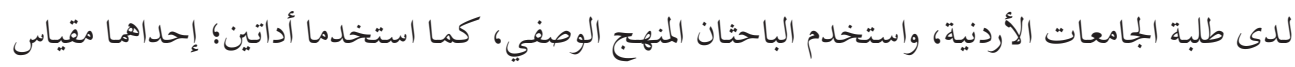

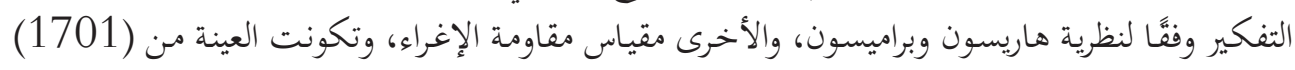

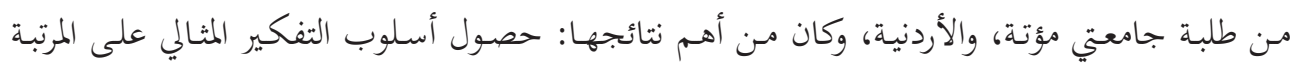

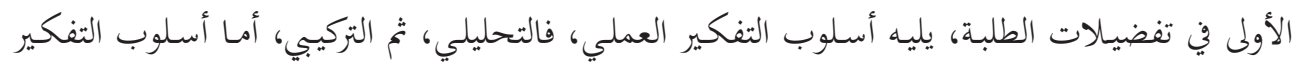

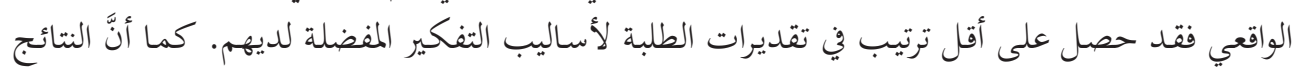

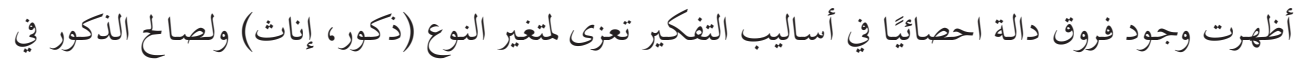

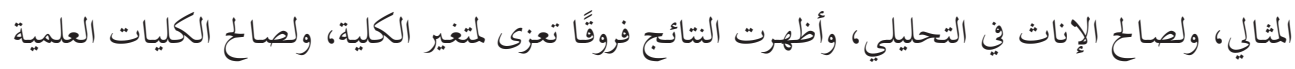
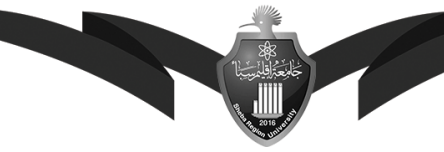
دراسة (محمد، 2014): هدفت إلى الكشف عن أساليب التفكير وعلاقتها بتقدير الذات

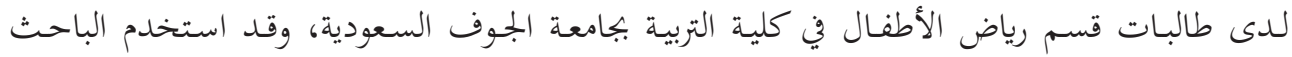

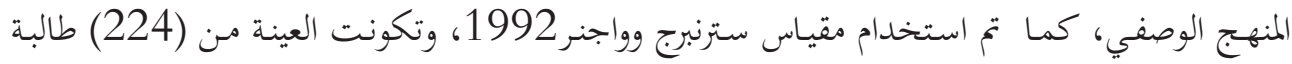

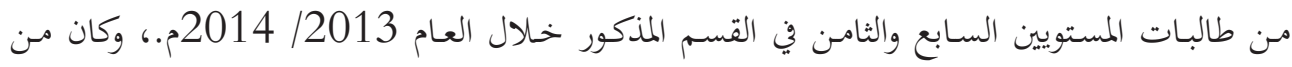

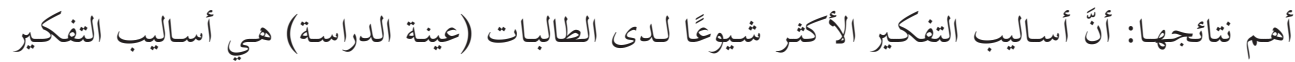

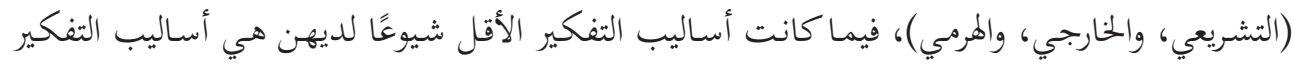

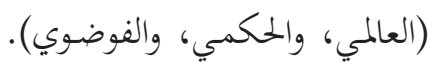

دراسة (الجميلي(2013): هدفت إلى الكشف عن أساليب التفكير الشائعة لدى طلبة الجامعات

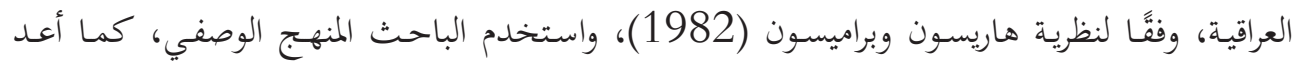

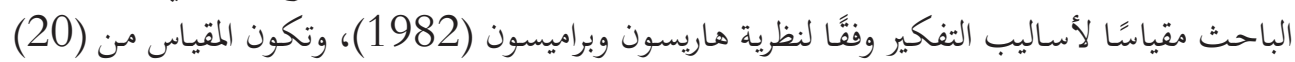

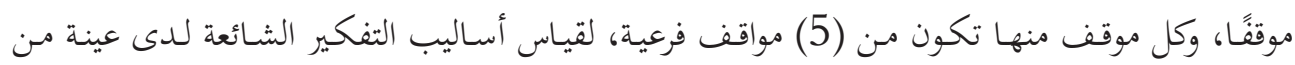

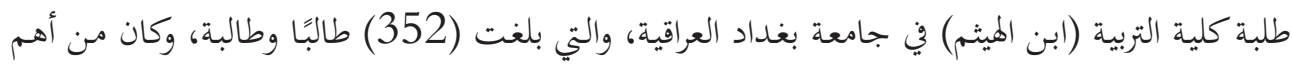

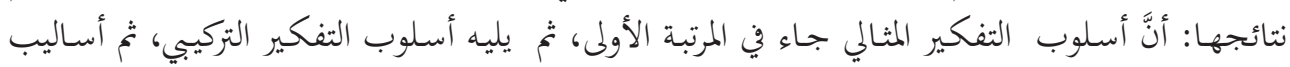

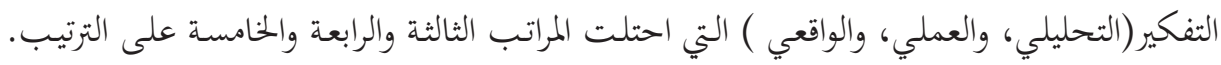
دراسة (النور،2013): هدفت إلى الكشف عن أساليب التفكير وعلاقتها بأساليب التعلم

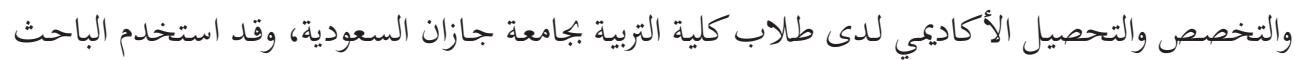

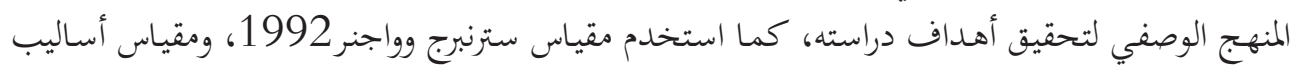

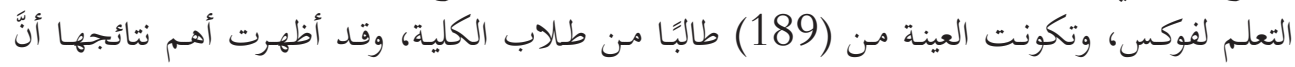

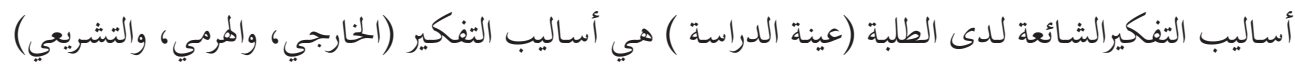
علي الترتيب، فيما لم تظهر النتائج وجود علاقة بين أساليب التفكير وأساليب التعلم. دراسة (بدر،2007): هدفت الدراسة إلى الكشف عن أساليب التفكير لدى طالبات جامعة الملك

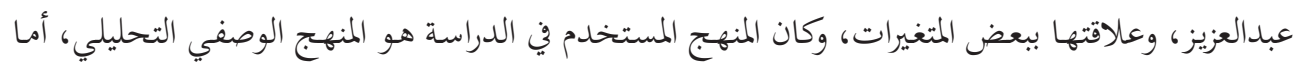

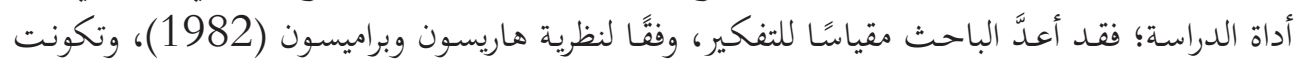

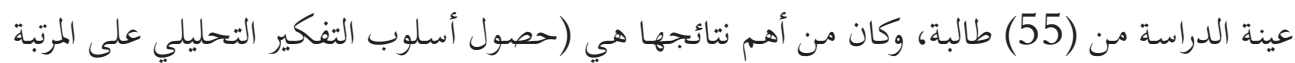

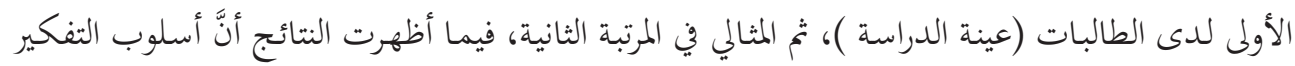
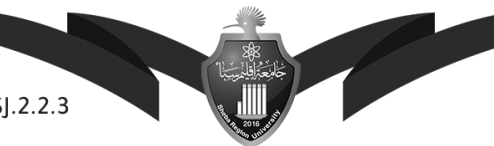

المجلد ( 2 ) - العدد ( 2 ( 2021 ) ديسمبر 2021م 


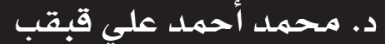

التحليلي يؤثر في ميل الطالبة إلى العمل وفقًا للمعايير الاجتماعية.

دراسـ(الزعبي، والشـيدة، 2007): هدفت إلى التعـرف على أسـاليب التفكير الشـائعة للدى طلبة جامعة طلال بن الحسـين في الأردن، واستخدم الباحثان المنهج الوصفي لتحقيق أهداف الدراسة، كما استخدما مقياس أساليب التفكير وفقًا لنظرية هاريسون وبراميسون(1982)،وتكونت ونست العينة من (140)

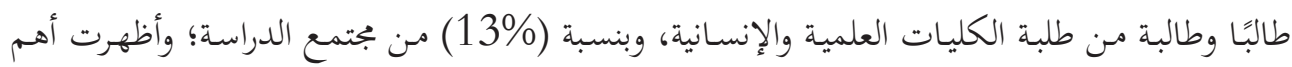
نتائجها: أن أكثر أسـاليب التفكير شيوعًا للدى الطلبة هو أسلوب التفكير الواقعي، يليه التحليلي، ثم

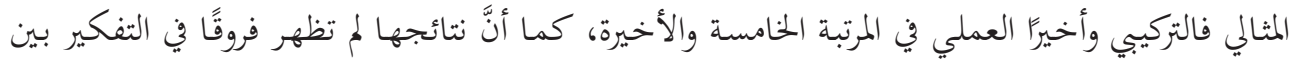

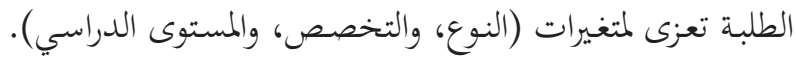

دراسة (طاحون، 2003): هدفت إلى المقارنة بين أساليب التفكير المفضلة لدى الطلبة الجامعيين

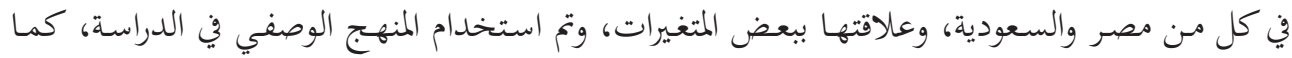

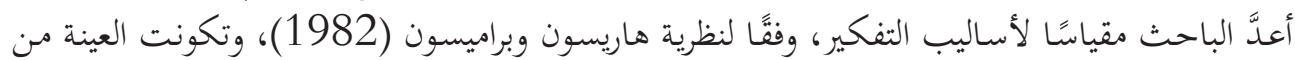

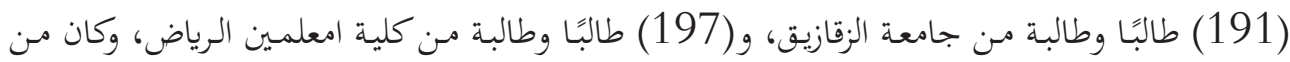

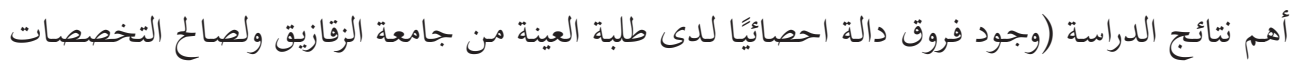
الأدبية، أمها الفروق في أسلوب التفكير التحليلي، فقد كانت لصالح طلبة التخصصات الإنسانية. دراسة اللهيبي (2001): هدفت إلى التعرف على أساليب التفكير المفضلة لدى معلمي ومعلمات التعليم العـام بمكة المكرمة، وعلاقتها ببعض المتغيرات (النوع، والمرحلة، والتخصص، والخـبرة، والمؤهـل)،

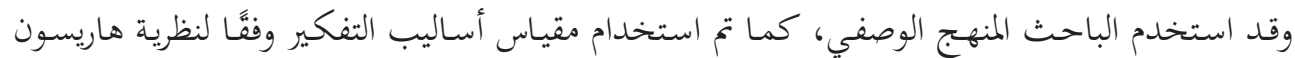
وبراميسون (1982))، وتكونت العينة مـن (619) معلمًا ومعلمـة مـن معلمي مـدارس التعليم العام

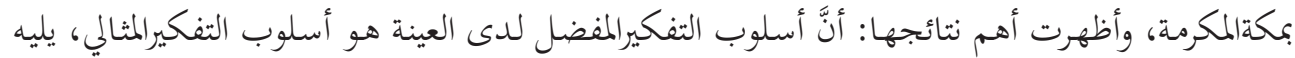
التحليلي، كما كشفت عن وجود فروق دالة إحصائية في أساليب التفكير المفضلة لديهم في أسلوب التفكيرالمثالي، ولصـالح المعلمات، بينما لم تظهر النتائج فروقا في أسـاليب التفكير وفقًا لمتغيرات (النوع، والمرحلة، والتخصص، والخبرة، المؤهل).

\section{ثالثًا: الدراسات الأجنبية:}

دراسة (2002) Bernardo, Zhang and calling): هدفت الدراسة إلى الكشف عن العلاقة بين أساليب التفكير والتحصيل لدى طلبة الجامعات في الفلبين، وتم استخدام المنهج الوصفي،

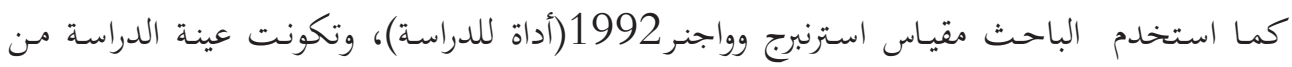


أساليب التفكير المفضلة لدى طلبة الدراسات العلياِِِ جامعة إقليهم سبأ اليمنية

وعلاقتها ببعض المتغيرات المضير التير

د. محمد أحمد علي قبقب

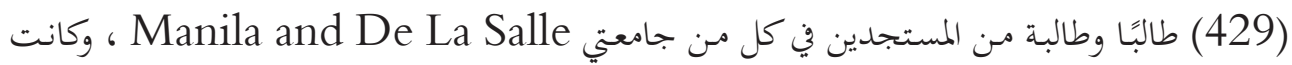
أهم نتائجها وجود علاقة ارتباطية ودالة احصائيًا بين كل من وطني أساليب التفكير والتحصيل الأكاديمي.

دراسة هوانج، وسيسكو (Huang and Sisco,1999): هدفت إلى مقارنة أساليب التفكير

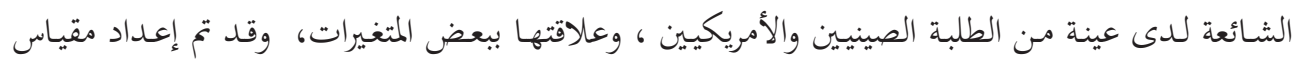

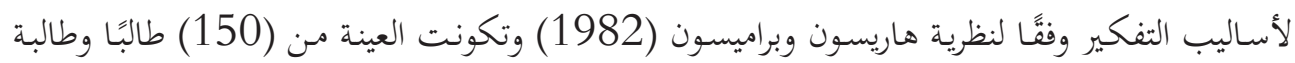

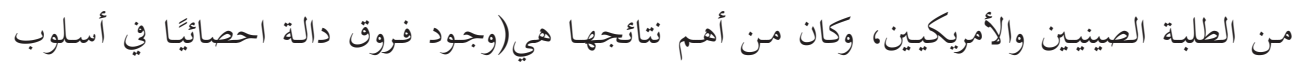

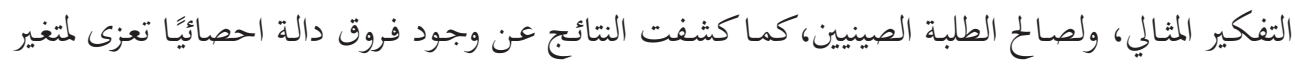
التخصص( تخصصات اجتماعية ، وتخصصات هندسية)، ولصالح التخصصات الفينات الهندسية. دراسة هوانج وتشيو (Huang and Chio,1999): هدفت إلى الكشف عن أساليب

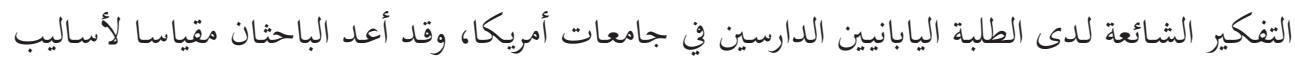

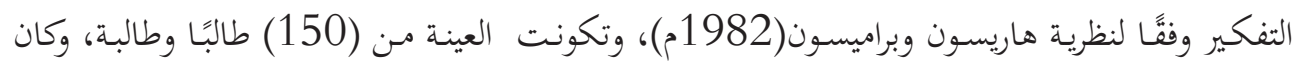

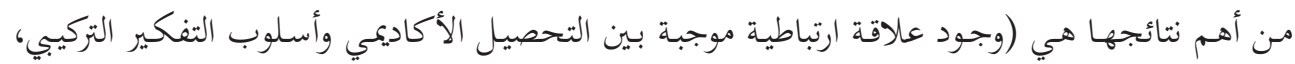

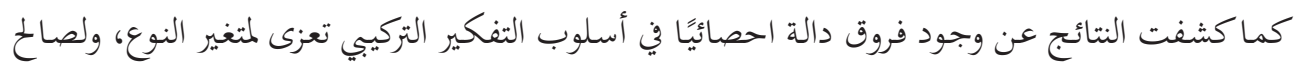
الذكور.

\section{التعليق على الدراسات السابقة:}

قام الباحث باستعراض الدراسات السابقة التي تم تناولتها الدراسة، من حيث أهدافها، ومنهجيتها،

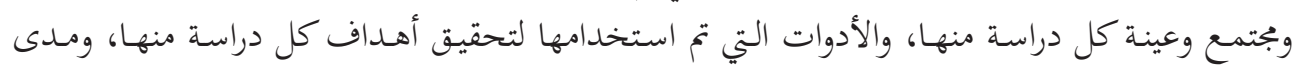

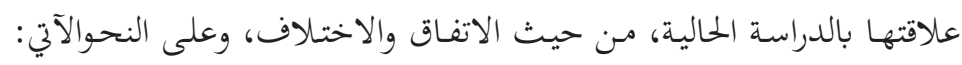

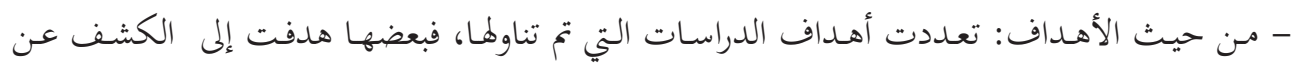

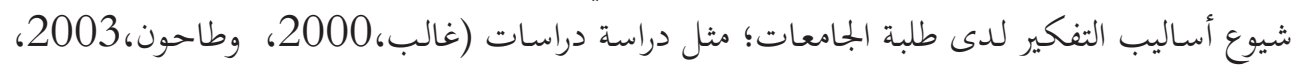

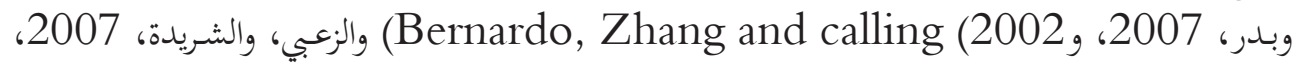

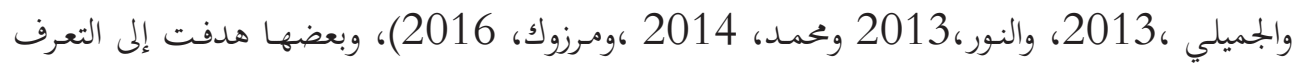

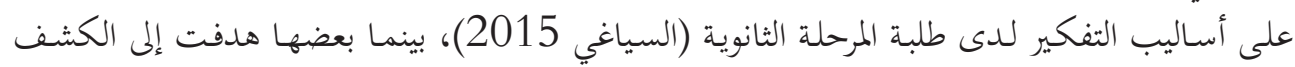

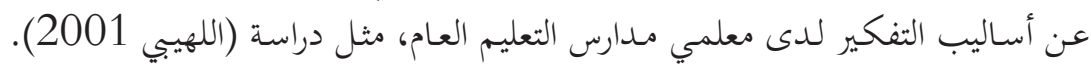

- من حيث المنهج: يلاحظ أنَّ جميع الدراسات التي تم استعراضها في الدراسة الحالية قد استخدمت
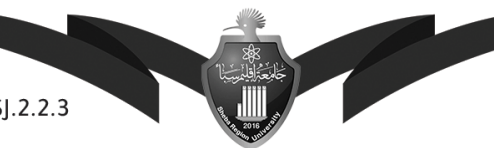

المجلد ( 2 ) - العدد ( 2 )

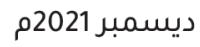


أساليب التفكير المفضلة لدى طلبة الدراسات العليايِ جامعة إقليم سبأ اليمنيـة

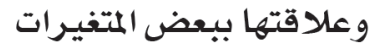

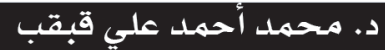

المنهج الوصفي لتحقيق أهدافها.

- من حيث المجتمع والعينة: معظم الدراسات التي تم تناوها كانت بتمعاها وعيناتها هم طلبة الجامعات،

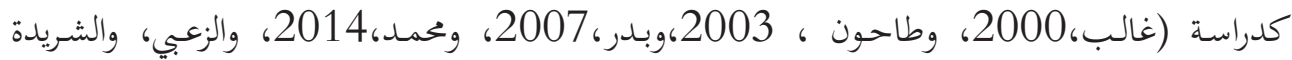

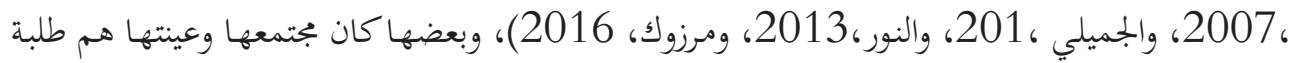

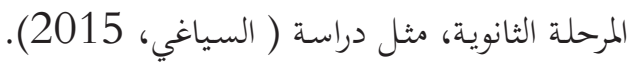

- من حيث الأداة : معظم الدراسات التي تم تناوها؛ كانت الأداة التي تم استخدامها لتحقيق أهداف كل

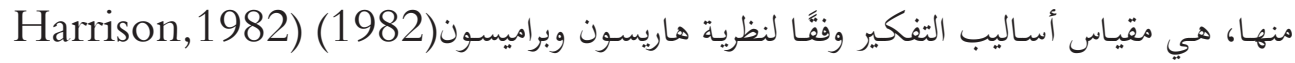
Bramison

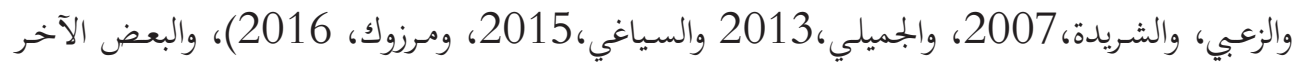

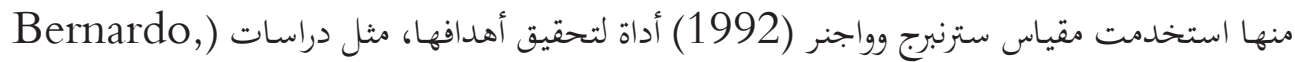
2002

استفادت الدراسة الحاليـة مـن الدراسـات السـابقة في تحديد منهج الدراسـة وإعـداد أداتها، ومعرفة الأساليب الإحصائية المستخدمة في تحليل وتفسير البيانات، واختلفت معها في عينتها، وبجتمعها، والبيئة الجغرافيـة التي نفذت فيها، والأداة التي تم اعدادها مـن قبل الباحثث لتحقيق أهـداف الدراسة. ووجه الأصالة في الدراسة الحالية هو تناولها لموضوع الكشف عن أساليب التفكير المفضلة لدى طلبة

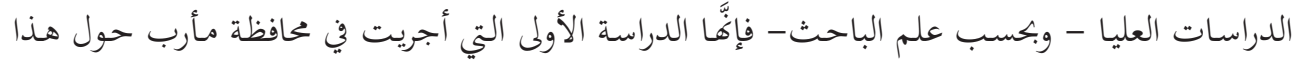

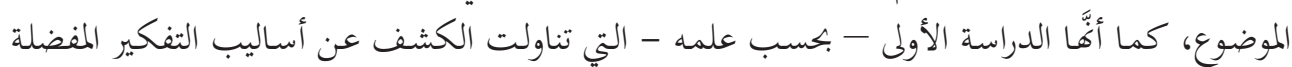
لدى طلبة الدراسات العليا على مستوى الجمهورية اليمنية . منهجية الدراسة وإجراءاتما :

منهجج الدراسـة: استخدم الباحث المنهج الوصفي التحليلي القائم على المسـح الميـاني لتحقيق أهـداف الدراسـة.

مجتمع الدراسة: اشتمل المجتمع على جميع طلبة الدراسات العليا في السنة التمهيدية في أقسام (الرياضيات، وعلوم القرآن، واللغة العربية، والمناهج وطرق التدريس، في كليتي (التربية والآداب والعلوم، وعلوم الحاسوب)، وعددهم (102) طالبًا وطالبة.

عينة الدراسة: اشتملت العينة على جميع الطلبة عينة الدراسة؛ بعد استبعاد الطبة الذين تم اختيارهم في

المجلد ( 2 ) - العدد ( 2 ) ديسمبر 2021م - لمجدم

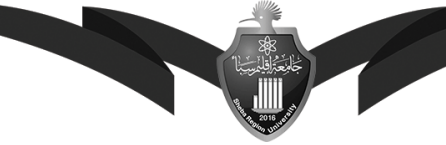


أساليب التفكير المفضلة لدى طلبة الدراسات العليايِّ جامعة إقليم سبأ اليمنية

ووعلاقتها ببعض المتغيرات المضيل

\section{د. محمد أحهد على قبقب}

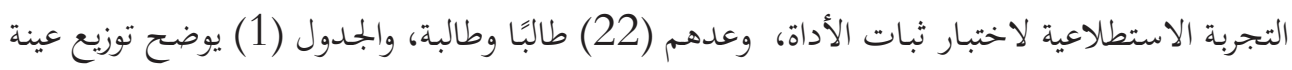
الدراسة تبعًا لمتغيرات النوع الاجتماعي والكلية والقسم الأكاديمي.

جدول(1) توزيع عينة الدراسة تبعًا لمتغيرات النوع والكلية والقسم الأكاديمي.

\begin{tabular}{|c|c|c|c|c|c|c|c|}
\hline \multicolumn{2}{|c|}{ العدد } & \multirow{2}{*}{ القسم } & \multirow{2}{*}{ الكلية } & \multicolumn{2}{|c|}{ العدد } & \multirow{2}{*}{ القسم } & \multirow{2}{*}{ الكلية } \\
\hline اناث & ذكور & & & اناث & ذكور & & \\
\hline \multirow{3}{*}{3} & \multirow{3}{*}{10} & \multirow{4}{*}{$\begin{array}{l}\frac{4}{2} \\
2 \\
1 \\
3 \\
j\end{array}$} & \multirow{4}{*}{ 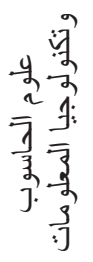 } & 6 & 16 & علوم قر آن & \multirow{4}{*}{ 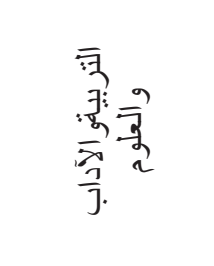 } \\
\hline & & & & 3 & 10 & لفة عربية & \\
\hline & & & & 8 & 14 & مناهج & \\
\hline \multirow{3}{*}{3} & & & & 3 & 9 & الرياضيات & \\
\hline & 10 & \multirow{2}{*}{\multicolumn{2}{|c|}{ 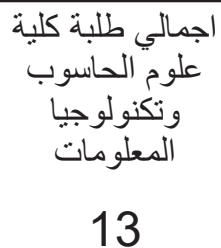 }} & 20 & 49 & & اجمالي طلبة كلية \\
\hline & & & & & \multicolumn{2}{|r|}{67} & \\
\hline \multicolumn{6}{|c|}{80} & \multicolumn{2}{|c|}{ الاجمالي الكلي } \\
\hline
\end{tabular}

أداة الدراسة: قام الباحث بإعداد أداة للكشف عن أساليب التفكير المفضلة لدى طلبة الدراسات العليا

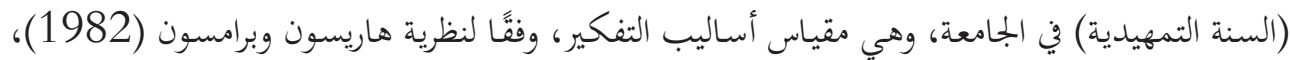
وقد تم إعداد هذا المقياس وفقًا للإجراءات الآتية:

الاطلاع على الأدبيات والدراسات السابقة: قام الباحثث بالاطلاع على الدراسات والبحوث التي

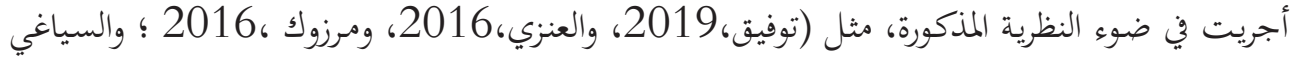

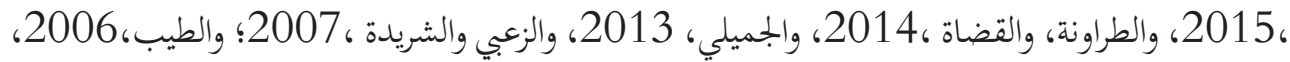

والشمسي ،2002، وغالب، 2000، ولطراة، وسترنبرج (Sternberg, 2004).

إعداد الصورة الأولية للمقياس: تكون المقياس في صورته الأولية مـ(18) موقفًا، ويتبع كل موقف منها

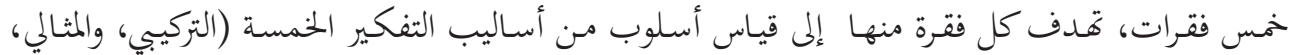

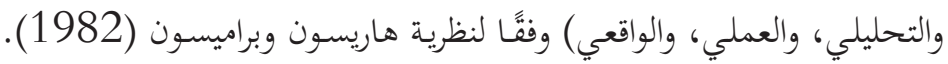
صدق المقياس: من أجل التأكد من صدق المقياس؛ تم عرضه بصورته الأولية على(12) عضوًا من أعضاء 


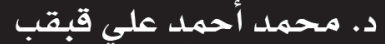

هيئة التدريس المتخصصين في المناهج وطرق التدريس، والقياس والتقويم، وعلم النفس؛ في جامعتي (إقليم

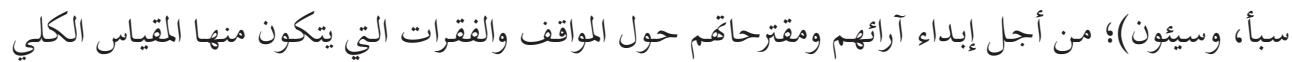

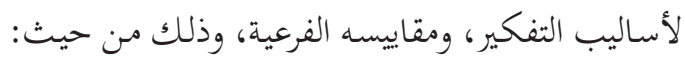

مناسبة الموقف وفقراته لقياس أسلوب التفكير الموضح أمام كل فقرة. انتماء الفقرة للموقف، وأسلوب التفكير الفرعي لها. سلامة الصياغة اللغوية للموقف وفقراته.

وفي ضوء ملاحظات المحكمين المتخصصين؛ فقد تم تعديل بعض الفقرات التي حصلت على أكثر

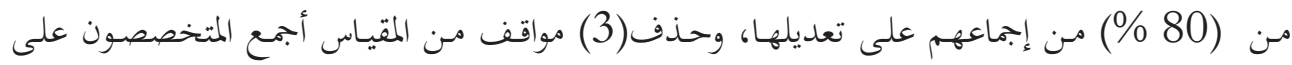

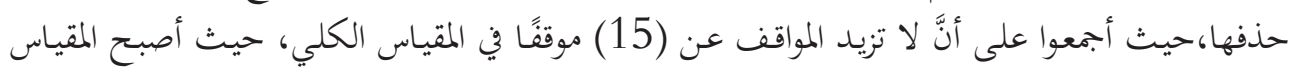

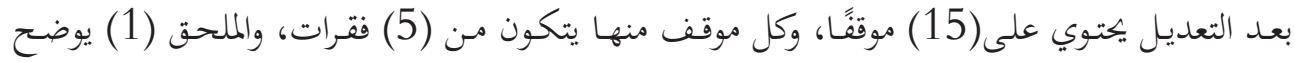

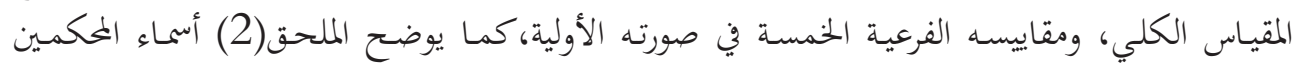

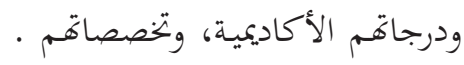

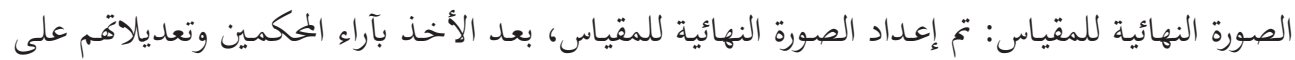

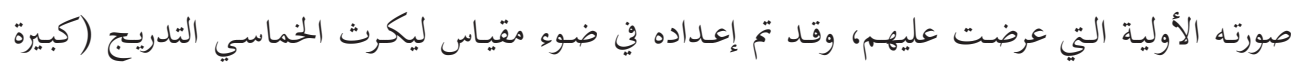

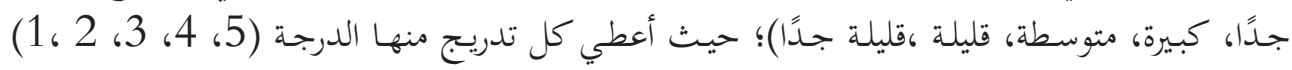

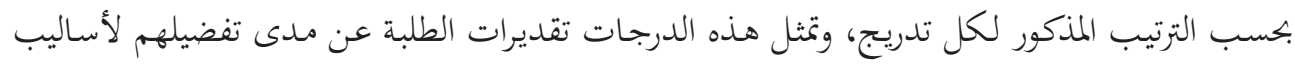

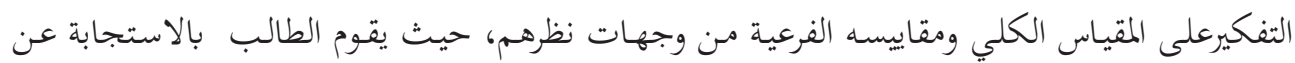

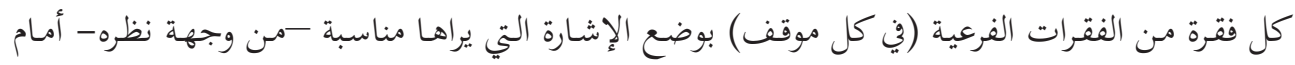

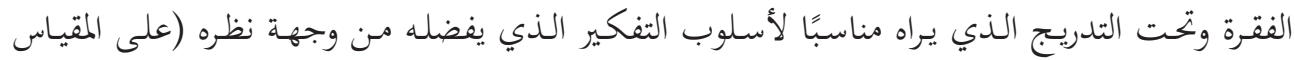
الكلي ومقاييسه الفرعية).

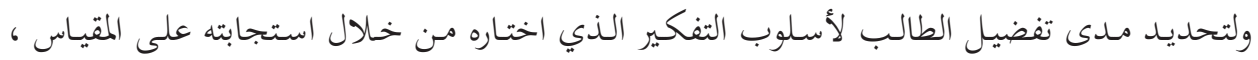

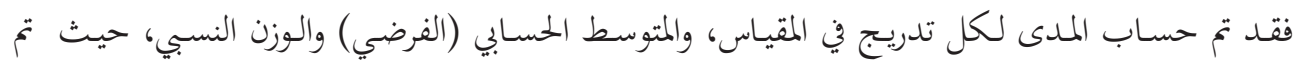

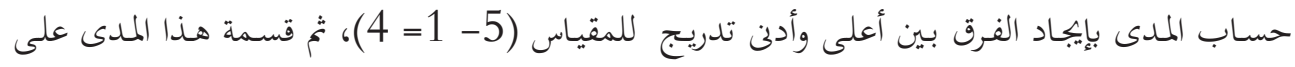

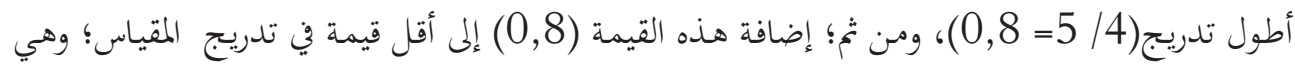

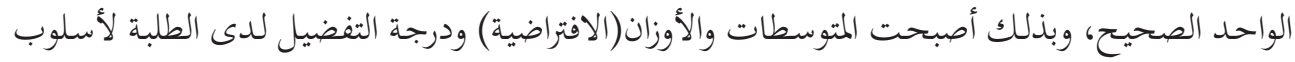

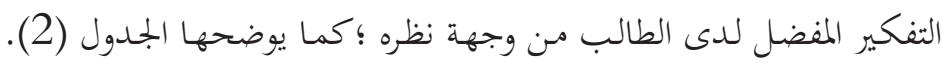

المجلد ( 2 ) - العدد (2021 (20) ديسمبر 2021م

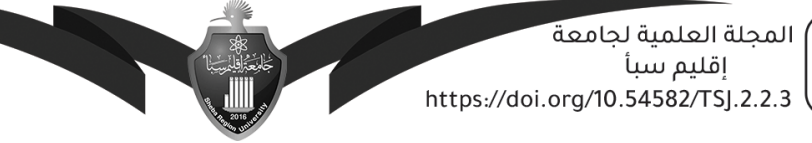


أساليب التفكير المفضلة لدى طلبة الدراسات العلياِِِ جامعة إقليم سبأ اليمنية

ووعلاقتها ببعض المتغيرات المضلي لدي

\section{د. محمد أحمد علي قبقب}

جدول(2)المتوسطات الحسابيةوالأوزان النسبية ودرجة التفضيل لأساليب التفكير لدى الطلبة على المقياس الكلي ومقاييسه الفرعية.

\begin{tabular}{|c|c|c|c|}
\hline درجة التفضيل & الوزن النسبي & المتوسط الحسابي & \\
\hline قليلة جدًا & من • † \%-اقل من דr\% & من |-أقل من ^, 1 & 1 \\
\hline قليلة & من דr\% إلى أقل من Y \% & من ^, 1 - أقل من Y, & 2 \\
\hline متوسطة & 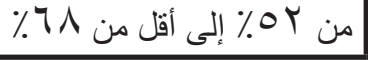 & 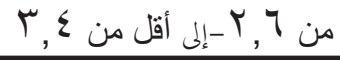 & 3 \\
\hline كبيرة & 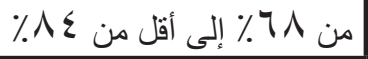 & 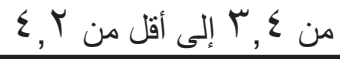 & 4 \\
\hline كبيرة جدًا & 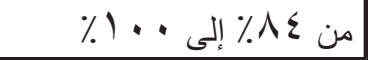 & من Y, א إلى 0 & \\
\hline
\end{tabular}

التطبيق الاستطلاعي للمقياس: تم التطبيق الاستطلاعي للمقياس على عدد (22) طالبًا وطالبة من طلبة إلى إلى

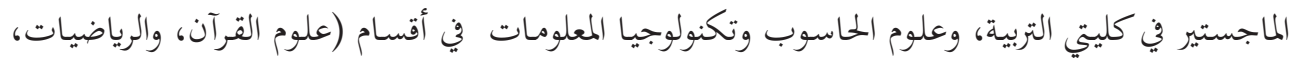

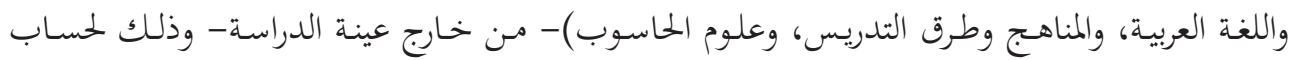

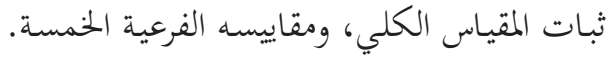

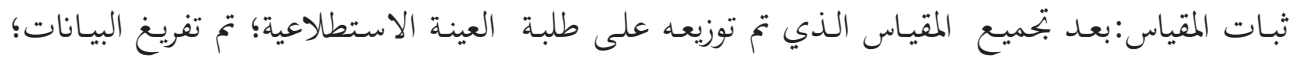

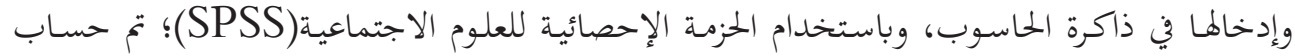

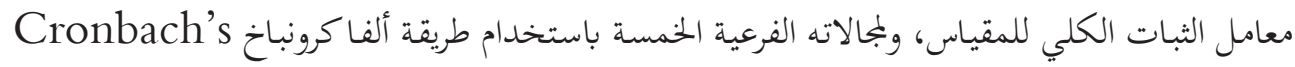
Alpha

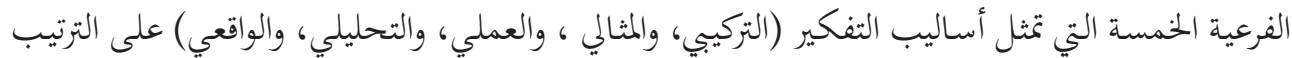

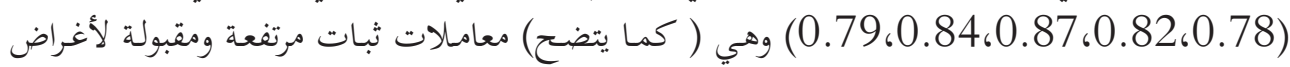

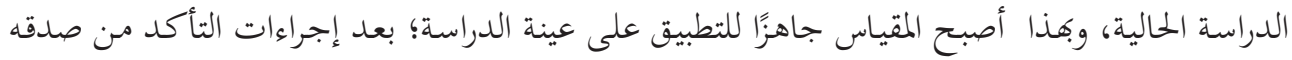
وثباته، والملحق (3) يوضح الصورة النهائية للمقياس.

التطبيق النهائي للمقياس: تم تطبيق المقياس من خلال الحنطوات الآتية:

بعد التأكد من صدق وثبات المقياس تم تطبيقه على جميع طلبة الدراسات العليا في جامعة اقليم سبأ

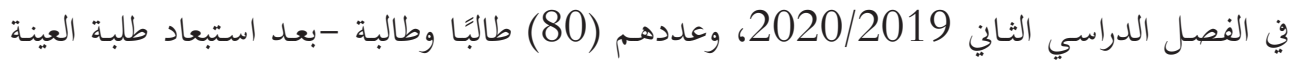

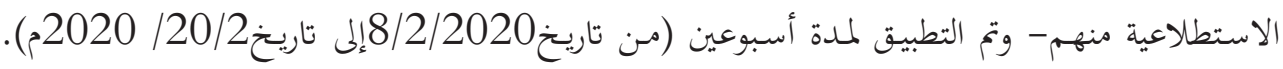
تم التطبيق من قبل الباحث بالالتقاء المباشر بالعينة في قاعاقمم الدراسية وتم توضيح الهدف من المقياس

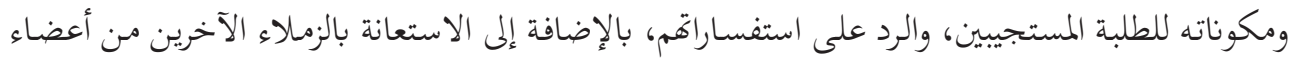


وأساليب التفكير المفضلة لدى طلبـة الدراسات العليايِ جامعة إقليم سبأ اليمنيـة وعلاقتها ببعض الميفر المتغيرات

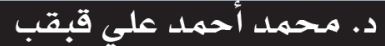

هيئة التدريس في برامج الماجستير.

بعد جمع نسخ المقياس من الطلبة (عينة الدراسة)، قام الباحث بإدخال البيانات في ذاكرة الحاسب الآلي باستخدام الحزمة الإحصائية للعلوم الاجتماعية (SPSS)، ولغرض تحليل البيانات، وتفسيرها، ومناقشة نتائج الدراسة؛ فقد استخدم الباحث الأساليب الإحصائية الآتية:

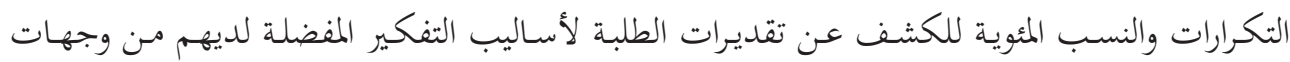
نظرهم (على المقياس الكلي ومقاييسه الفرعيـة) المتوسطات الحسابية والانحرافات المعيارية. معادلة ألفاكرونباخ. (لحساب ثبات المقياس، ومقاييسه الفرعية). الوسط الافتراضي (المرجح)؛ لمعرفة مدى تدريج المقاييس الفرعية.

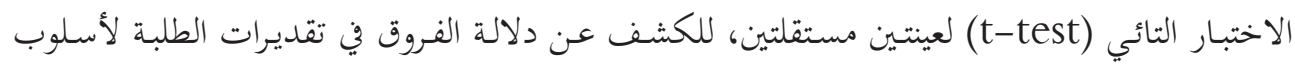
التفكير المفضل لديهـم مـن وجهات نظرهـم (على المقيـاس الكلي ومقاييسه الفرعية).

\section{عرض نتائج الدراسة:}

للإجابة عن السؤال الأول من أسئلة الدراسة والذي ينص على : ما مدى شيوع أساليب التفكير المفضلة

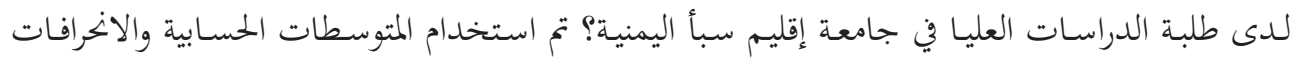
المعيارية والوزن النسبي، وذلك للكشف عن تقديرات طلبة كلية التربية في مدى تفضيلهم لأساليب التفكير على المقياس الكلي ومقاييسه الفرعية من وجهة نظرهم، والجمدول (3) يوضح ذلك. جدول(3) المتوسطات الحسابية والاخخرافات المعيارية لتقديرات الطلبةعن مدى شيوع لأساليب التفكير المفضلةعلى المقياس الكلمي ومقاييسه الفرعية.

\begin{tabular}{|c|c|c|c|c|c|c|}
\hline الترتيب & المئويةة. & مدى التفضبل & الوزن النسبي ٪ & الانعياري اف & الحستوسطي & أسلفكير \\
\hline 5 & 18.2 & قليلة & 43.2 & 7.4 & 32.5 & التركيبي \\
\hline 4 & 19.4 & قليلة & 46.2 & 6.7 & 34.7 & المثالي \\
\hline 3 & 20 & قليلة & 48 & 6.4 & 35.9 & العملي \\
\hline 2 & 21 & قليلة & 49.6 & 6.1 & 37.1 & التحليلي \\
\hline 1 & 21.4 & قليلة & 51 & 7.5 & 38.2 & الو اقعي \\
\hline & & قليلة & 47.6 & 22.6 & 178.5 & المقياس الكلي \\
\hline
\end{tabular}

المجلد ( 2 ) - العدد ( 2 ) ديسمبر 2021م - (20دمد

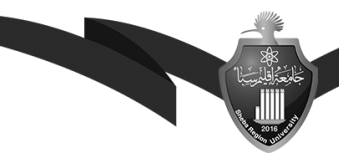


أساليب التفكير المفضلة لدى طلبة الدراسات العلياِِّ جامعة إقليم سبأ اليمنية

وعلاقتها ببعض المتغيرات الميري

\section{د. محمد أحمد علي قبقب}

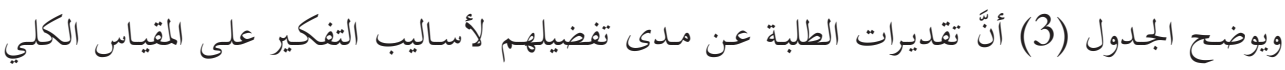

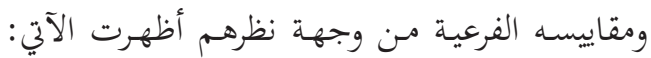

حصول أسلوب التفكير الواقعي على المرتبة الأولى من بين أساليب التفكير الخمسة في الدراسة الحالية،

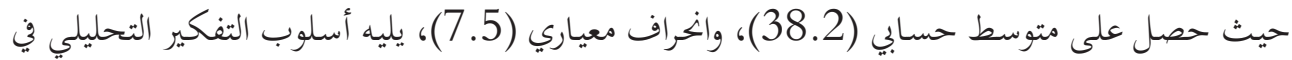

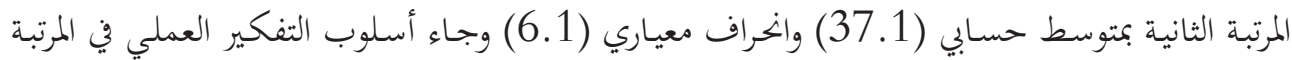

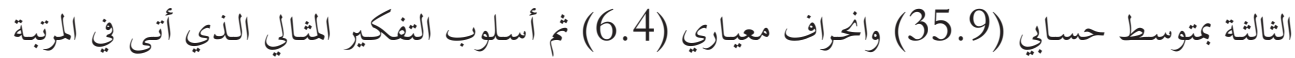

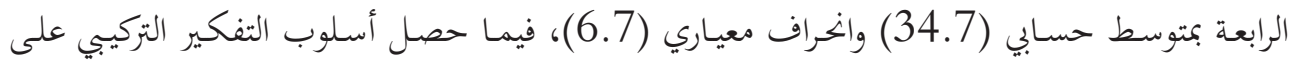

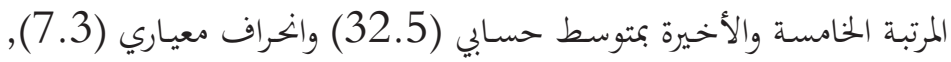

كما أظهرت النتائج أنَّ مدى شيوع أساليب التفكير المفضلة لدى طلبة الدراسات العليا؛ على المقياس الكلي، أومقاييسه الفرعية كانت (قليلة).

اتفقت هذه النتيجة مع نتائج دراسة (الزعبي، والشريدة ،2007) في ترتيب أساليب التفكير الخمسة

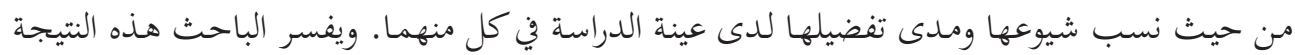

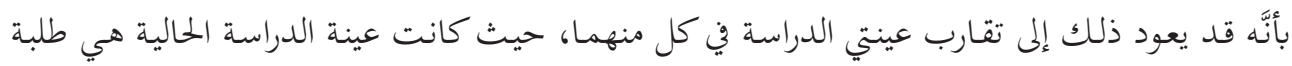

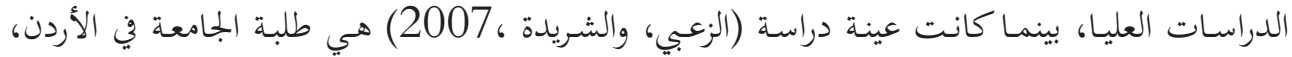

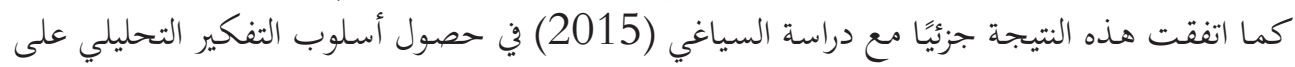
الترتيب الرابع في تقديرات أفراد العينة فيهما.

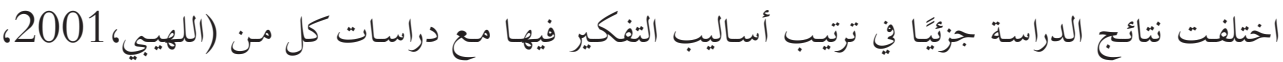

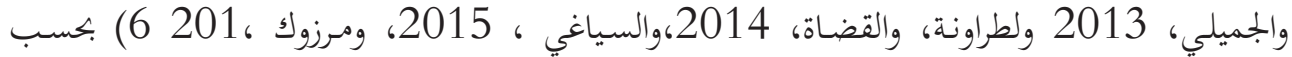

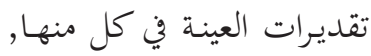

ويرى الباحث أنَّ هذا الاختلاف قد يعود إمَّا إلى اختلاف البيئة الجغرافية والثقافية والاجتماعية؛ كما

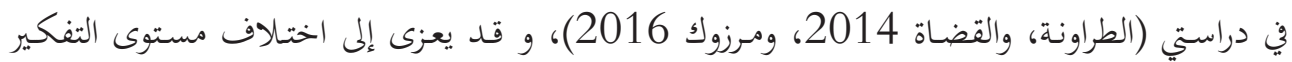

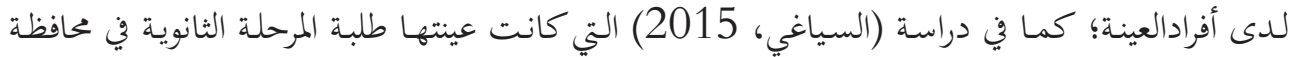
تعز اليمنية.

ولإجابة عن السؤال الثاني من أسئلة الدراسة والذي ينص على:هل توجد فروق ذات دلالة إحصائية

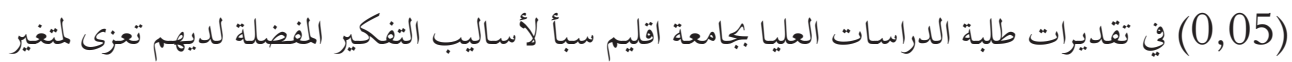


أساديب التفكير المفضلة لدى طلبة الدراسات العليايِّ جامعة إقليهم سبأ اليمنية وعلاقتها ببعض الميفر المتغيرات

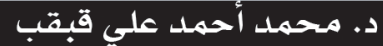

الكلية (تربية،علوم حاسوب)؟ تم استخدام المتوسطات الحسابية والانحرافات المعيارية واختبار (t-test)

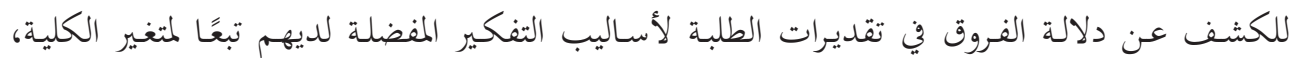
والجدول(4) يوضح ذلك.

جدول (4) اختبار ( t-test) للكشف عن دلالة الفروق في تقديرات الطلبة لأساليب التفكيرالمفضلة لديهم تبعًا لمتغيرالكلية (تربية،علوم حاسوب).

\begin{tabular}{|c|c|c|c|c|c|c|c|}
\hline \multicolumn{6}{|c|}{ أسلوب التفكير } & & \multirow{3}{*}{ الكلية } \\
\hline \multirow{2}{*}{$\overline{3} \overline{3}, \bar{y}$} & \multirow{2}{*}{$\overline{9}$} & \multirow{2}{*}{ 可; } & \multirow{2}{*}{$\overline{3}$} & \multirow{2}{*}{$\overline{3}$} & \multirow{2}{*}{ 皇 } & \multirow{2}{*}{ علوم حاسوبة } & \\
\hline & & & & & & & \\
\hline 180.7 & 37.3 & 29.5 & 35.6 & 38.8 & 31.9 & تربية & \multirow{2}{*}{ الحستابي } \\
\hline 163.6 & 36.7 & 30.2 & 365 & 37.1 & 32.5 & علوم حاسوب & \\
\hline 22.8 & 6.03 & 5.3 & 1.6 & 7.7 & 5.3 & تربية & \multirow{2}{*}{ الانحر افياري } \\
\hline 14.6 & 7.07 & 6.6 & 6.7 & 4.6 & 7.6 & علوم حاسوب & \\
\hline \multicolumn{6}{|c|}{78} & & د. حرية \\
\hline 2.3 & 0.63 & 2.72 & 2.01 & 1.9 & 0.27 & & قيمة ت \\
\hline 0.025 & 0.53 & 0.008 & 0.50 & 0.57 & 0.78 & & دلالة إحصائية \\
\hline
\end{tabular}

ويتضح من الجمدول (4) أنَّ نتائج اختبار (t-test) أظهرت الآتي:

عدم وجهود فروق دالة احصائيًا في تقديرات الطلبة لأسـاليب التفكير المفضلة لديهمم تبعًا لمتغير الكلية (تربية، علوم حاسوب) على أيّ مـن أسـاليب التفكير الخمسـة التي اشتملت عليها الدراسـة.

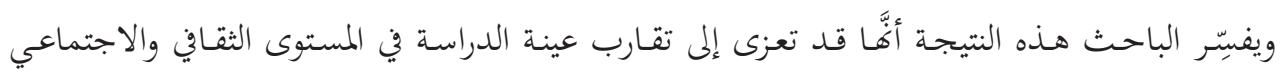
والاقتصادي للطلبـة في الكليتـين.

اتفقت نتائج الدراسة مع دراسة (الزعبي، والشريدة، 2007) في عدم وجود فروق دالة في تقديرات الطلبة

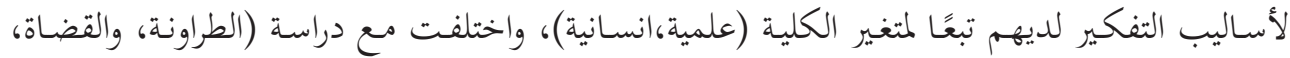
2014) التي أظهرت فروقا دالة احصائيًا في تقديرات الطلبة لأساليب التفكير لديهم تبعًا لمتغير الكلية في أسلوبي التفكير(العملي والتركيبي) ولصالح العلمية منها.

ولإجابة عن السؤال الثالث من أسئلة الدراسة والذي ينص على: هل توجد فروق ذات دلالة إحصائية

المجلد (2 2 ) - العدد (2021 (20) ديسمبر 2021م

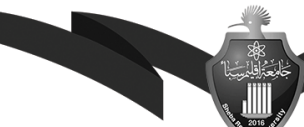


أساليب التفكير المفضلة لدى طلبة الدراسات العلياِِِ جامعة إقليم سبأ اليمنية

وعلاقتها ببعض المتغيرات

\section{د. محمدل أحمد على قبقب}

(0,05) في تقديرات طلبة الدراسات العليا بجامعة اقليم سبأ اليمنية لأسـاليب التفكير المفضلة لديهم

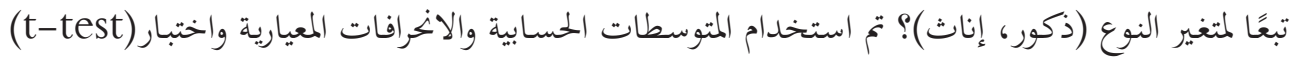

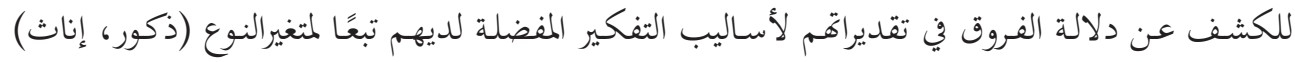

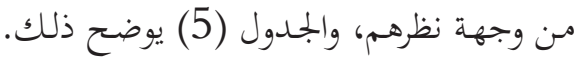
جدول (5) اختبار (t-test) للكشف عن دلالة الفروق في تقديرات طلبة الدراسات العليا لأساليب

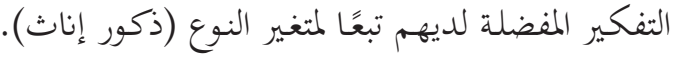

\begin{tabular}{|c|c|c|c|c|c|c|c|}
\hline \multicolumn{6}{|c|}{ أسلوب التفكير } & \multicolumn{2}{|c|}{ المتغير } \\
\hline \multirow{2}{*}{ 景司, } & \multirow{2}{*}{ क } & \multirow{2}{*}{ 可 } & \multirow{2}{*}{$\overline{3}$} & \multirow{2}{*}{$\overline{\overline{3}} \overline{\bar{x}_{3}}$} & \multirow{2}{*}{ 皇 } & ذكور & \multirow{2}{*}{ الاجتماعي } \\
\hline & & & & & & إناث & \\
\hline 179.4 & 37.94 & 34.83 & 36.5 & 37.7 & 32.5 & ذكور & \multirow{2}{*}{ الحسابي } \\
\hline 180.04 & 35.61 & 34.7 & 36.22 & 40.1 & 33.4 & إناث & \\
\hline 23.4 & 5.8 & 7.3 & 6.9 & 7.5 & 7.6 & ذكور & \multirow{2}{*}{ الانحر افياري } \\
\hline 19.3 & 6.03 & 5.4 & 6.4 & 8.3 & 6.6 & إناث & \\
\hline \multicolumn{6}{|c|}{78} & & د. حرية \\
\hline-0.11 & 1.6 & 0.08 & 0.18 & -1.2 & -0.5 & & قيمة ت \\
\hline 0.91 & 0.10 & 0.94 & 0.38 & 0.20 & 0.6 & & دلالة إحصائية \\
\hline
\end{tabular}

ويوضح الجمدول (5) أنَّ نتائج اختبار(t-test) في تقديرات طلبة الدراسات العليا لأساليب التفكير

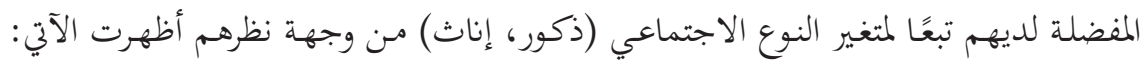

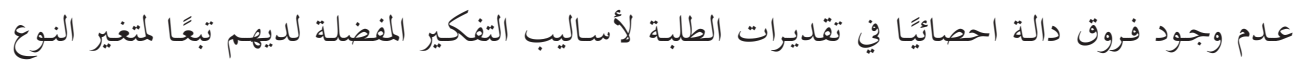

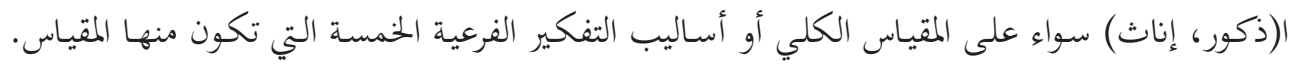

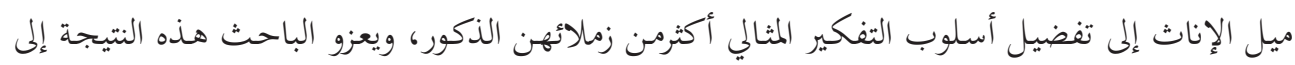

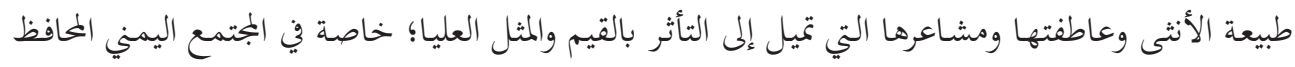

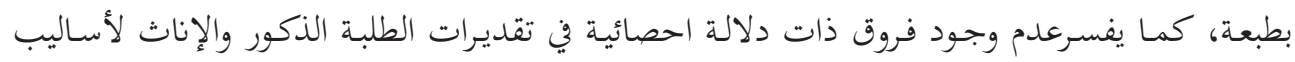

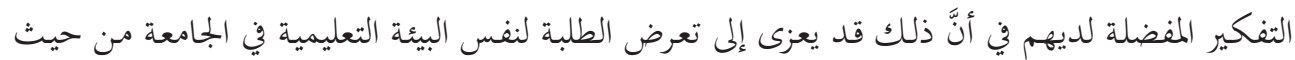
الأنشطة وأساليب التدريس والتجهيزات.

اتفقت نتائج هذه الدراسة مع نتائج دراسة الزعبي، والشريدة (2007) والتي أظهرت عدم وجود فروق 
أُساليب التفكير المفضلة لدى طلبة الدراسات العليايِّ جامعة إقليم سباً اليمنيـة وعلاقتها ببعض التفكير المتغيرات المغات

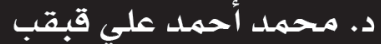

دالة احصائيًا تبعًا لمتغير النوع (ذكور، إناث).

اختلفت نتائجها جزئًا مع دراسـة (السياغي، 2015) التي كشفت نتائجها عن وجـود فرق دال إحصائًا في أسلوب التفكير التحليلي، ولصالح الإناث، وكذلك وجود فرق دال في أسلوب التفكير التركيبي لنفس المتغير، ولصالح الإناث.

ولإجابة عن السؤال الرابع من أسئلة الدراسة والذي ينص على : هل توجد فروق ذات دلالة إحصائية (0,05) في تقديرات طلبة الدراسات العليا لأساليب التفكير المفضلة لديهم تعزى لمتغير القسم الأكاديمي توني

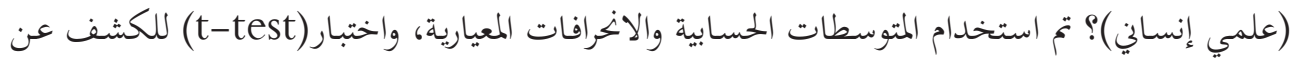

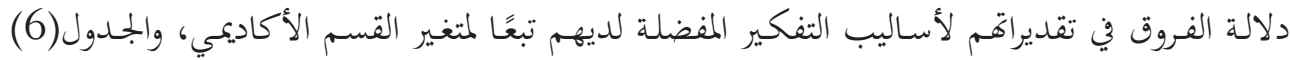
يوضح ذلك.

جـدول (6) اختبـار( test) للكشف عن دلالة الفروق في تقديرات طلبة الدراسات العليا لأسـاليب التفكير المفضلة لديهم تبعًا لمتغير القسم (علمي، إنساني).

\begin{tabular}{|c|c|c|c|c|c|c|c|}
\hline \multicolumn{6}{|c|}{ أسلوب التفكير } & \multicolumn{2}{|c|}{ المتغير } \\
\hline \multirow{2}{*}{ المقياس } & \multirow{2}{*}{ الو اقعي } & \multirow{2}{*}{ التحليلي } & \multirow{2}{*}{ العملي } & \multirow{2}{*}{ المثالي } & \multirow{2}{*}{ التركيبي } & علمي & \multirow{2}{*}{ الأكاديمي القسم } \\
\hline & & & & & & إنساني & \\
\hline 175.9 & 36.9 & 34.7 & 36.8 & 38.3 & 31.5 & علمي & \multirow{2}{*}{ الحسابي } \\
\hline 179.7 & 37.66 & 34.84 & 35.73 & 38.18 & 30.28 & إنساني & \\
\hline 14.4 & 5.41 & 5.34 & 5.67 & 8.79 & 5.01 & علمي & \multirow{2}{*}{ الانحر افياري } \\
\hline 18.5 & 6.42 & 7.31 & 6.77 & 6.96 & 7.05 & إنساني & \\
\hline \multicolumn{6}{|c|}{78} & & د. حرية \\
\hline-0.7 & -1.1 & 0.11 & 0.5 & 0.08 & -1.9 & & قيمة ت \\
\hline 0.5 & 0.3 & 0.07 & 0.7 & 0.9 & 0.07 & & دلالة إحصائية \\
\hline
\end{tabular}

المجلد ( 2 ) - العدد ( 2 ) ديسمبر 2021م - لمجدم

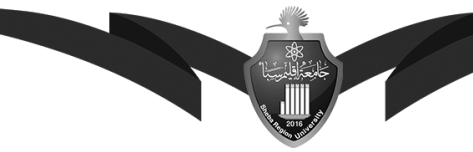


ويوضح الجدول (6) نتائج اختبار( t-test) في تقديرات طلبة الدراسات العليا لأساليب التفكير المفضلة لديهم تبعًا لمتغير القسم الأكاديكي (علمي، إنساني) من وجهة نظرهم، حيث أظهرت تلك أنك النتائج الآني:

عدم وجود فروق ذات دلالة إحصائية في تقديرات طلبة الدراسات العليا لأساليب التفكير المفضلة لديهم

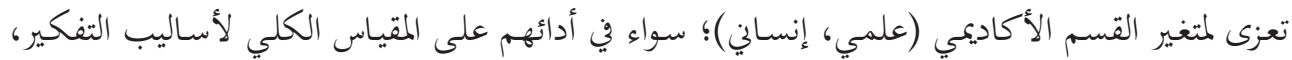

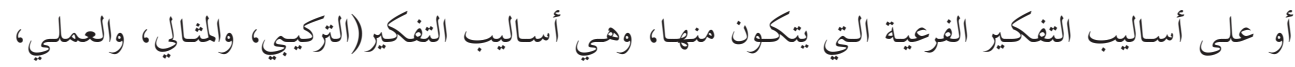
والتحليلي، والواقعي).

ويفسر الباحث هذه النتيجة في عدم وجود فروق دالة احصائيًا في أساليب التفكير التي يفضلها الطلبة

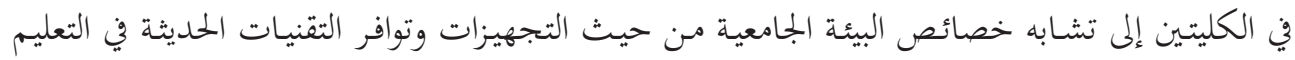

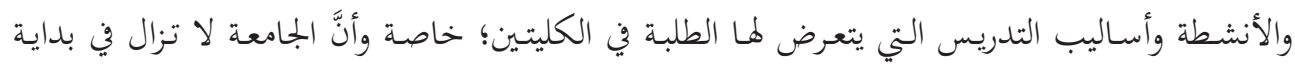
مراحل نشأقتا من حيث البنية التحتية.

اتفقت نتائج الدراسة مع نتائج دراسة الزعبي، والشريدة (2007) التي لم تظهر نتائجها وجود فروق ذات التيات

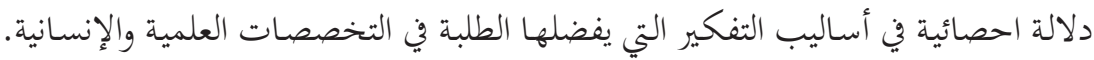

اختلفت نتائجها جزئيا مع نتائج دراسة مرزوك (2016) التي أظهرت وجود فرق دال إحصائيًا في التئي

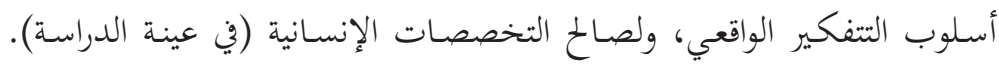




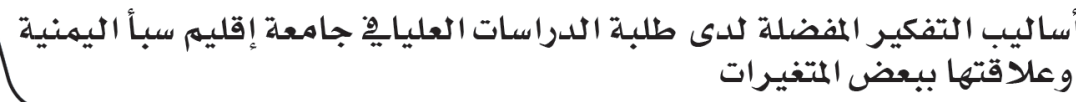

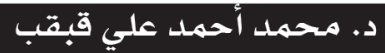

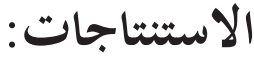

من خلال نتائج الدراسة، فقد توصل الباحث إلى أهم الاستنتاجات الآتية:

أنَّ عينة الدراسة من الطلبة متقاربون في تفضيالهم لأساليب التفكير التي يستخدموفا في تعاملهم في حل مشكاكاهم التي تعترضهم في البيئة المحيظة بهم، أو في حياتم العملية.

حصول أسلوب التفكير الواقعي على المرتبة الأولى في تقديرات الطلبة (أفراد العينة) لأسـاليب التفكير المفضلة لديهم.

حصول أسلوب التفكير المثالي على المرتبـة الرابعة في تقديرات الطلبة (أفراد العينة) لأسـاليب التفكير المفضلة لديهـم. 
أساليب التفكير المفضلة لدى طلبة الدراسات العلياِِّ جامعة إقليم سباً اليمنية

وعلاقتها ببعض المتغيرات المضير التير

د. محمد أحهد علي قبقب

\section{التوصيات والمقترحات:}

أولَا : التوصيات: في ضوء ما تمَّ التوصل إليه من نتائج ، يوصي الباحث بالآتي:

توجيه اهتمام أعضاء هيئة التدريس في الجامعة إلى ضرورة الكشف عن أساليب التفكير المفضلة

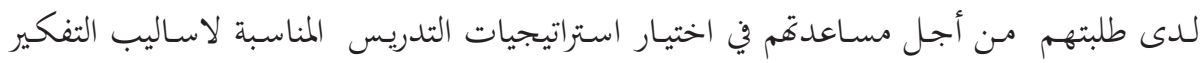
الشائعة لدى الطلبة.

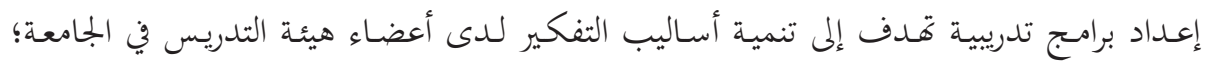
خاصة من يقومون بالتدريس في برامج الدراسات العليدا.

تفعيل دور المؤسسات التربوية في الاهتمام بإعداد برامج توعوية وتثقيفية وإرشادية تمدف إلى تنمية أساليب التفكير لدى أفراد المجتمع.

ثانيًا: المقترحات: في ضوء نتائج الدراسة واستنتاجاها؛ نظرًا لأنَّ الدراسة محدودة في عينتها وفي نطاقها

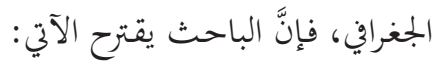

إجراء دراسات عن أساليب التفكير وعلاقتها بالذكاءات المتعددة لدى طلبة الدراسات العليا في جامعة اقليم سبأ.

إجراء دراسات تتناول العلاقة بين أساليب التفكير وأسـاليب التعلم لدى طلبة المرحلة الجامعية الأولى في كليات وأقسام الجامعة المختلفة.

إجراء دراسات تتناول العلاقة بين أساليب التفكير ومتغيرات التحصيل الأكاديمي، والتسويف التفيف

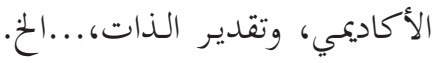




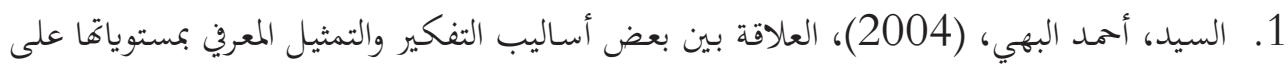

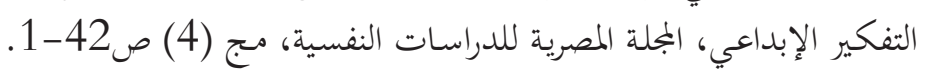

2. توفيق، جنان محمد (2019)، أساليب التفكير وعلاقتها بمستوى الطموح لدى طلبة الجامعات،

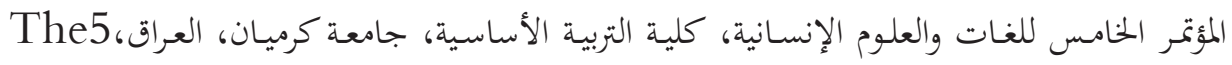
Conference for the language and Human Sciences, (Special Is-

. sue

3. الجميلي، مؤيد حامـد جاسم، (2013)، أ ساليب التفكير وأساليب التعلم لدى طلبة الجامعات

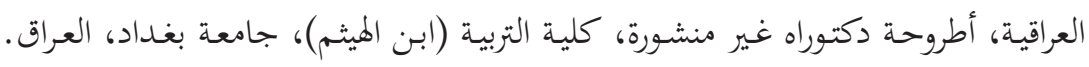
4. ديبونو، إدوارد (2001)، تعليم التفكير: ترجمة ( عادل عبد الكريم ياسين، وإياد أحمد حلمي، دار اللغة للنشر، القاهرة.

5. دناوي، مؤيد أسعد حسين (2008)، تطوير مهارات التفكير الإبداعي ،ط1، مكتبة النهضة

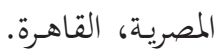

6. سترنبرج، وروبرت، (2004)، أساليب التفكير، ترجمة: عادل سعد يوسف، ط1، مكتبة النهضة المصرية، القاهرة.

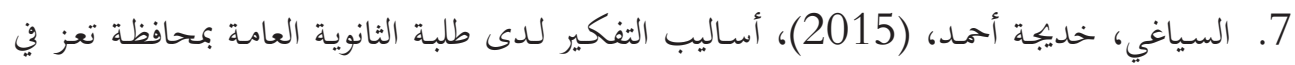

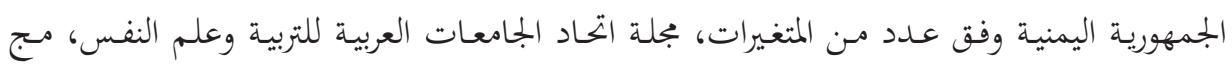

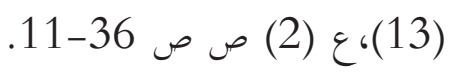

8. الشمسي، عبد الأمير عبود، (2004)، أساليب التفكير لدى طلبة الجامعة، جامعة بغداد، بجلة

$$
\text { العلوم النفسية، ع (1) (1). }
$$

9. الطيب، عصام علي، (2006)، أساليب التفكير (نظريات ودراسات وبحوث)، عالم الكتب، القاهرة.

01. الطراونة، صبري، والقضاة، محمد أمين، (2014)، العلاقة بين مقاومة الإغراء وأنماط التفكير

المجلد ( 2 ) - العدد (2021 (20) ديسمبر 2021م

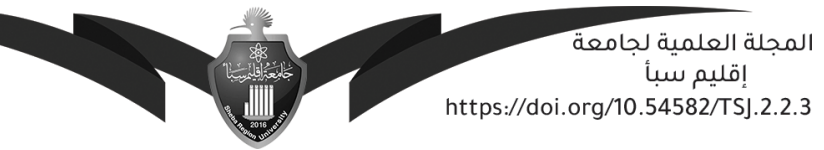


السائدة لدى الطلبة الجامعيين، المجلة الأردنية في العلوم التربوية، مج (10)، ع (1)، ص ص-89

11. العنزي، عبد الله عبد الهادي (2016)، أساليب التفكير ومستوى الطموح الأكاديمي ودورهما

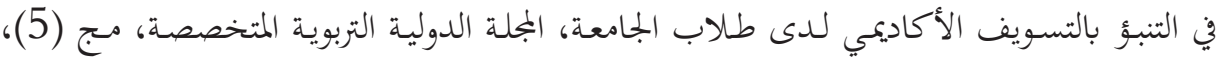

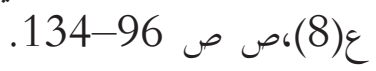

12.علي، بشرى حسين، وصاحب وجدان عناد (2010)، أساليب التفكير وعلاقتها بمستوى الطموح

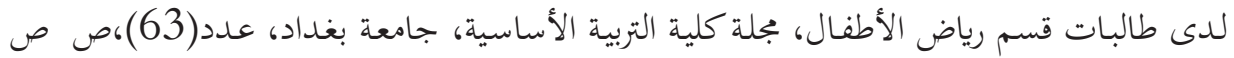

$$
330-279
$$

13.غالب ردمـان محمد سعيد (2001)، أساليب التفكير لدى معلمي الثانوية قبل الخدمة، كلية

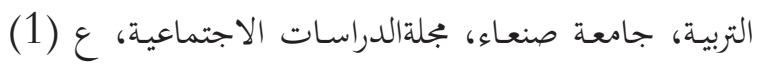

14.العتوم، عدنان يوسف (2004)، علم النفس المعريف (النظرية والتطبيق)، دار المسيرة للنشر والتوزيع،

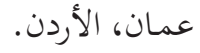

15.مرزوك، أحمدممد (2016)، أساليب التفكير وعلاقتها بالاتحاهات التعصبية عند طلبة الجامعة،

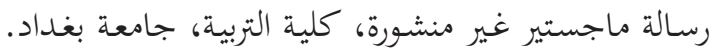

61. محمد، طارق ( 2002) أنماط التفكير الاستراتيجي وأثرها في اتخاذ القرار، ط2، دار الكتاب،عمان، ردان الأردن.

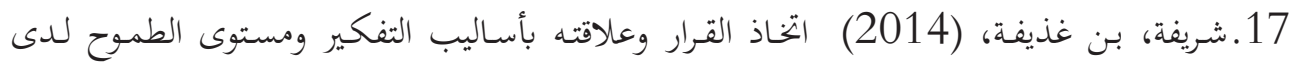

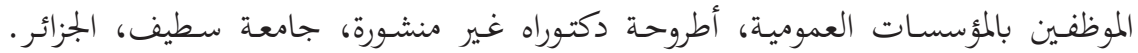

81. طاحون، حسين (2003) ،أساليب التفكير لدى طلبة الجامعة وعلاقتها ببعض المتغيرات (دراسة

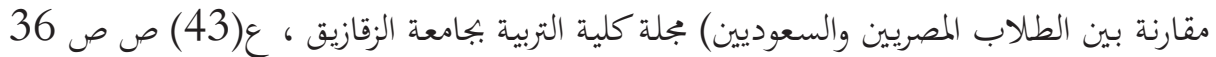


أساليب التفكير المفضلة لدى طلبـة الدراسات العليايِ جامعة إقليم سباً اليهنيـة

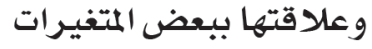

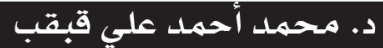

19. Bayer, B.K. (1988). Development a scope and sequence for thinking skills instruction". Educational Leadership, Vol 45, no.7. 20. Grigorenko, E. and Sternberg, R. (1995), Styles of thinking in the School, European Journal for high ability pp 201- 219.

21. Sternberg, R.(1997), Thinking styles, Cambridge University York.

22. Harrison, A. \& Bramison, R. (1982). Styles of thinking strategies for asking questions, making decisions, and solving-problems. Anchor

23. Huang A.and Chio L. (1999), Japanese college students thinking style, Psychological report No.(75) pp 143- 146.

24. Huhng R.J. and Sisco B.R.(1999), Thinking styles of Chinese and American adult students in higher Education and Computer study, Psychological report No.(74) pp 475- 480.

25. Sternberg, R.J. \& Zhang, L.F (2006): Styles of Thinking as abases of differentiated instruction, theory into practice $\mathrm{v},(44), \mathrm{N}$ (3), P 245-253.

26. Bernardo, A., Zhang Li-Fang and Calling C. (2000) Thinking Style and Academic achievement among Filipino Students Journal of Genetic psychology Vol 163, (2) PP. 149 - 163.

المجلد ( 2 ) - العدد ( 2 ( 2021 )

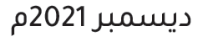

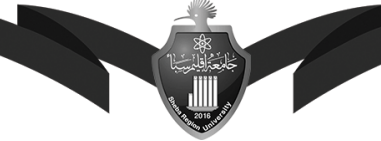


أساليب التفكير المفضلة لدى طلبة الدراسات العليايِّ جامعة إقليم سبأ اليمنية

ووعلاقتها ببعض المتغيرات المضيل

\section{د. محمد أحهد على قبقب}

ملحق(1) مقياس أساليب التفكير بصورته النهائية.

أخي الطالب / أختي الطالبة:

يقوم الباحث بإجراء دراسة تهدف إلى الكشف عن الطن اله أساليب التفكير المفضَّلة لدى طلبة الدراسات

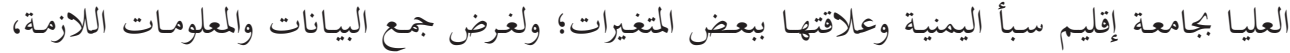

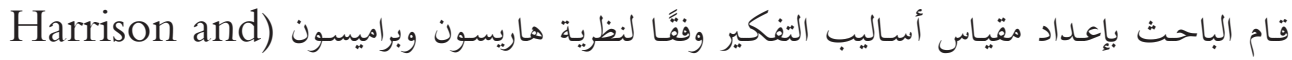

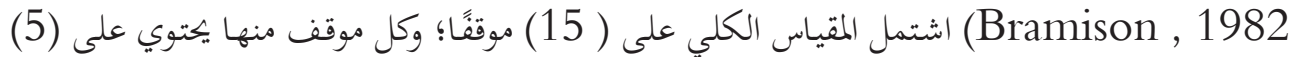

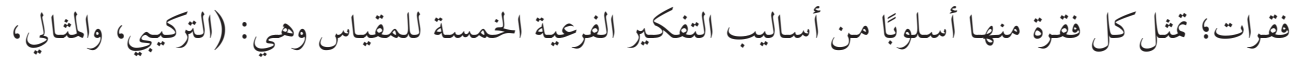
والعملي، والتحليلي، والواقعي). يرجى تكرمكم بالإجابة عن جميع مواقف وفقرات المقياس، وعدم ترك ألي أي موقف أو فقرة بدون إجابة.

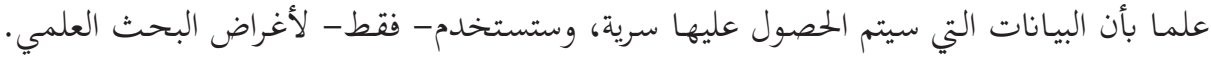

\begin{tabular}{|c|c|c|c|c|c|c|}
\hline \multicolumn{5}{|c|}{ درجة شيوع أسلوب التفكير } & \multirow{2}{*}{ 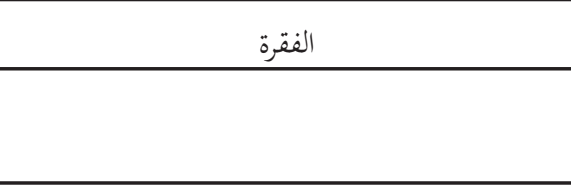 } & \multirow[t]{2}{*}{ s } \\
\hline \multirow[t]{2}{*}{ قليلة } & قليلة & 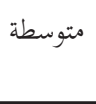 & كبيرة & كبيرة جدا & & \\
\hline & & & & & \multicolumn{2}{|c|}{ إذا حدثت مشكلة بين بعض أصدقائك، فإِنَّ الذي ستقوم به لحلها: } \\
\hline \multirow[t]{3}{*}{$\sqrt{ }$} & & & & & الربط بين مظاهر المشكلة وأسباهما . & 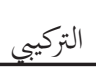 \\
\hline & $\sqrt{ }$ & & & & حل المشكلة وفقًا للنظم واللوائح . & 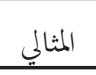 \\
\hline & & 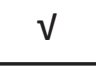 & & & إشراك أشخاص آخرين للمساعدة في حل المشكلة . & 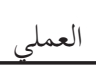 \\
\hline \multirow[t]{2}{*}{$\sqrt{ }$} & & & & & تجزئة المشكلة ليسهل حلها . & 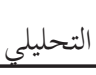 \\
\hline & $\checkmark$ & & & & وضع حلول بما يعالج أسباب المشكلة . & 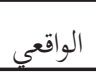 \\
\hline
\end{tabular}

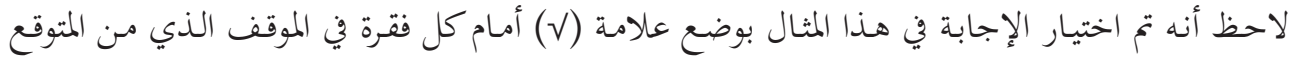

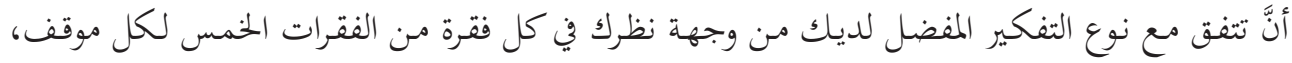

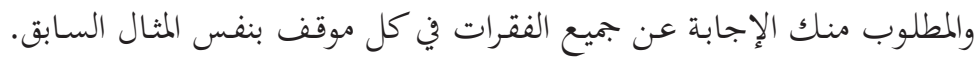

الباحث: د/ محمد قبقب. 
أساليب التفكير المفضلة لدى طلبة الدراسـات العليايِ جامعة إقليم سبأ اليمنية

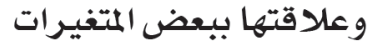

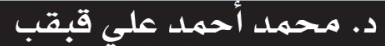

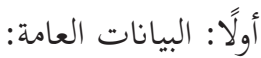

القسم: رياضيات $\square$

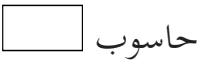

النوع الاجتماعي: ذكر: $\square$

ثانيًا: مواقف وفقرات المقياس :

\begin{tabular}{|c|c|c|c|c|c|c|c|}
\hline \multicolumn{5}{|c|}{ درجة شيوع أسلوب التفكير } & \multirow{2}{*}{\multicolumn{2}{|c|}{ الموقف وفقراته }} & \\
\hline $\begin{array}{l}30 \\
13 \\
13\end{array}$ & 雳: & 宗 & 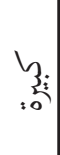 & $\begin{array}{l}3 ; \\
\vdots \\
1 \\
1\end{array}$ & & & \\
\hline & & & & & \multicolumn{2}{|c|}{ إذا طلب منك إبجاز مهمة؛ فإنَّ أول شيء ستعرفه عن } & \\
\hline & & & & & اختيار أفضل طريقة لإنجاز المهمة من عدة & 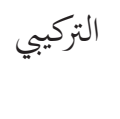 & 1 \\
\hline & & & & & مناسبة المهمة للقيم والمثل الاجتماعية . & 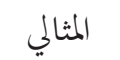 & \\
\hline & & & & & المهمة تستحق الجهاز الذيازها سيبذل في & & \\
\hline & & & & & المهام الفرعية اللازمة لإنجاز المهة . & التحليلي & \\
\hline & & & & & الفائدة التطبيقية للمهمة . & الواقعي & \\
\hline & & & & & نقاش عن موضوع معين؛ فإنَّك تميل إلى : & إذا دخلل & \\
\hline
\end{tabular}

المجلد ( 2 ) - العدد ( 2 ( 2 ( ديسمبر 2021م 
أساليب التفكير المفضلة لدى طلبة الدراسات العليايِ جامعة إقليم سبأ اليمنية

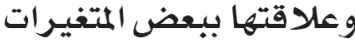

\section{د. محمدل أحمد علي قبقب}

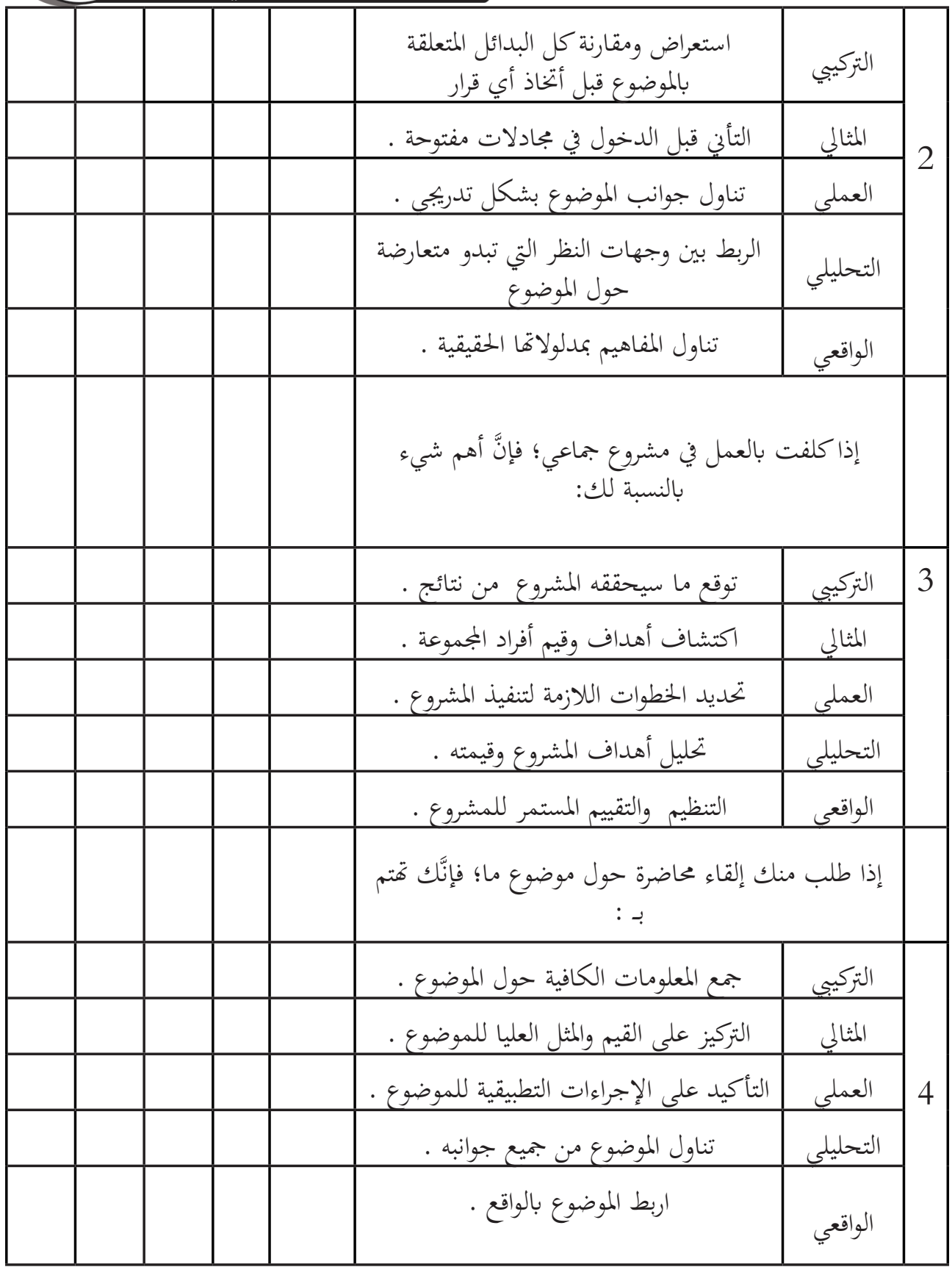




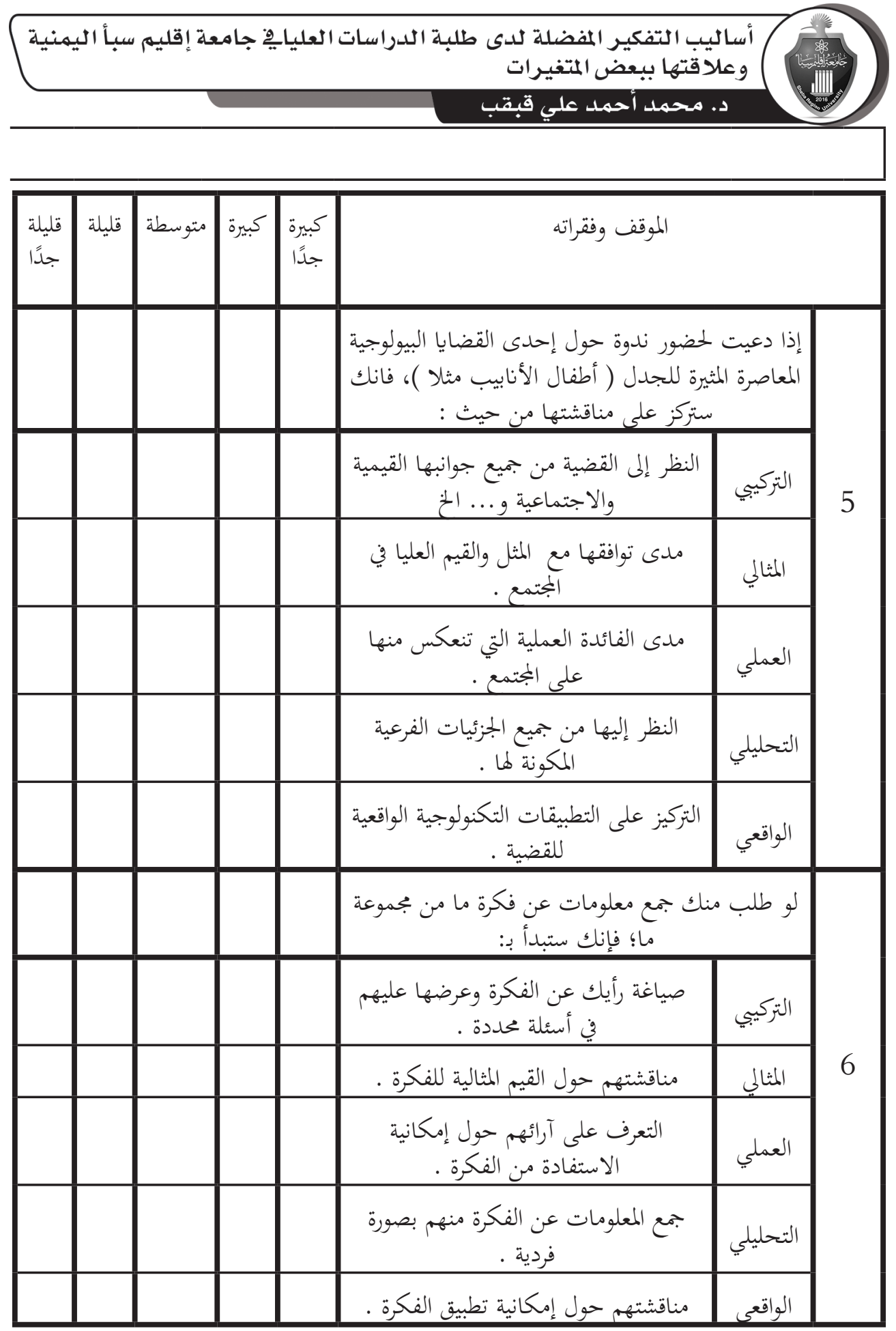

المجلد ( 2 ) - العدد ( 2 ) ديسمبر 2021م

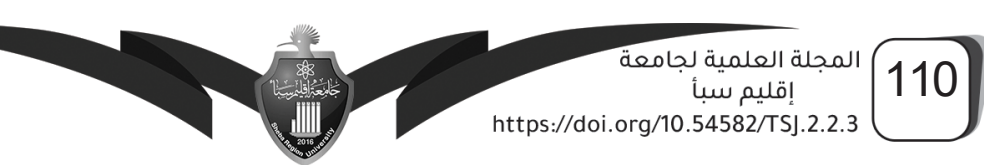




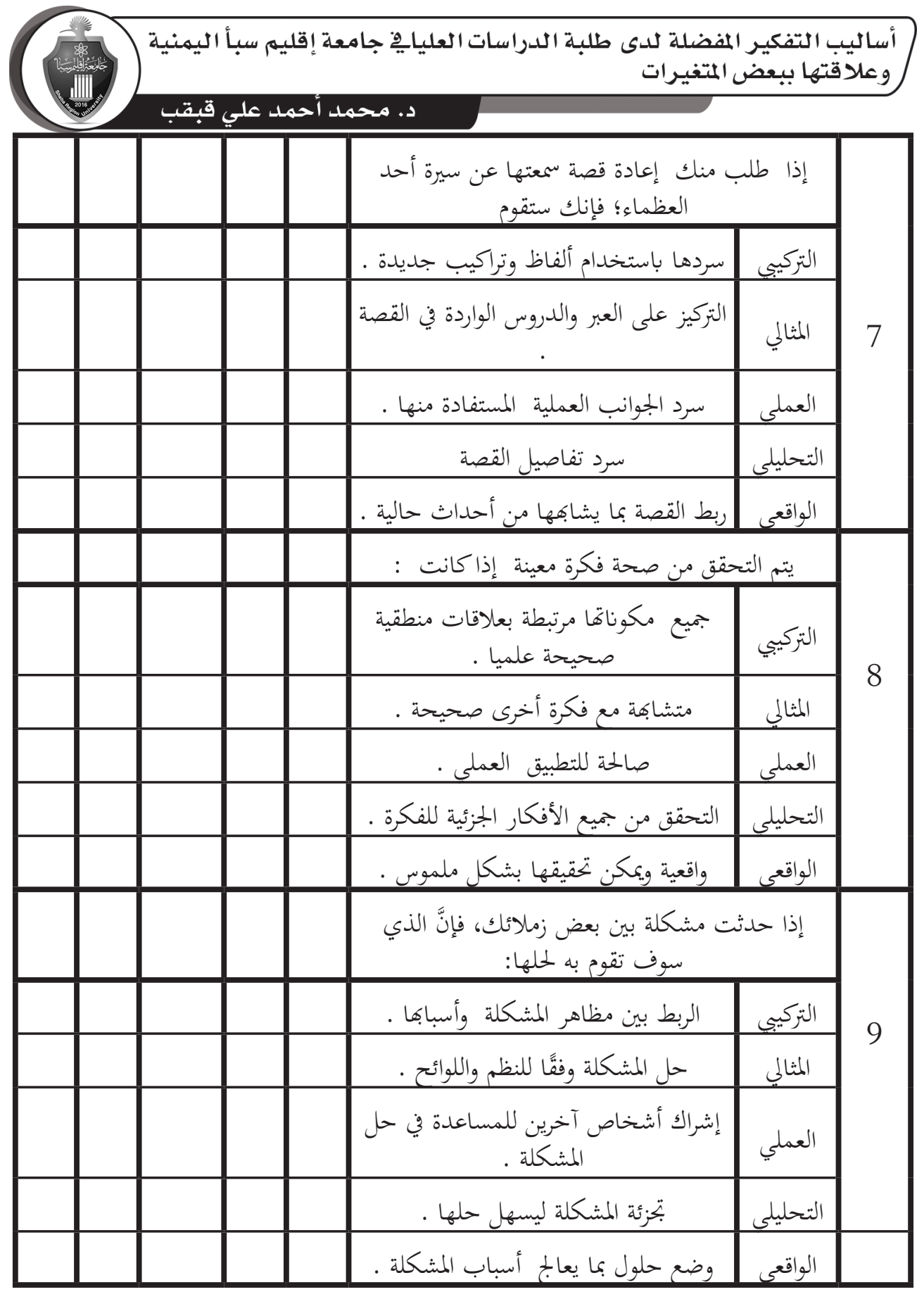




\begin{tabular}{|c|c|c|c|c|c|c|c|}
\hline \multicolumn{8}{|c|}{ 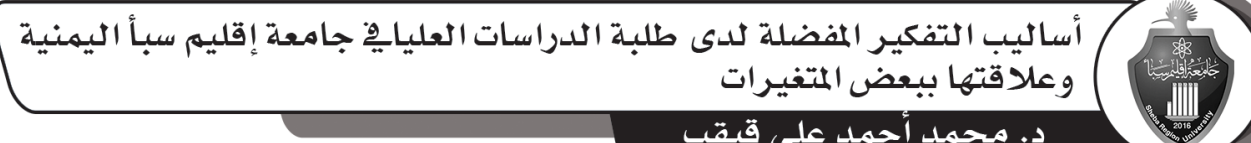 } \\
\hline & & & & & \multicolumn{2}{|c|}{ 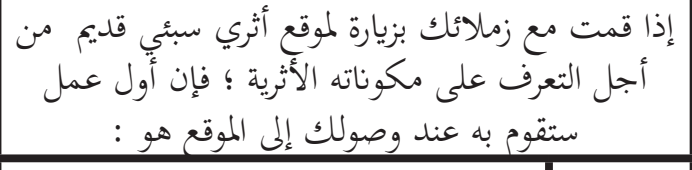 } & \multirow{6}{*}{10} \\
\hline & & & & & القيام بجولة شاملة لللموقع. & التركيبي & \\
\hline & & & & & التركيز على المكونات الرمزية الحضارية في & 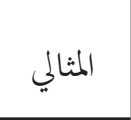 & \\
\hline & & & & & التركيز على المكونات المفيدة في الموقع . & 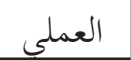 & \\
\hline & & & & & $\begin{array}{l}\text { التعرف على جميع التفاصيل الأثرية } \\
\text { الموجودة في الموقع · }\end{array}$ & & \\
\hline & & & & & التركيز على الملكونات التي تشكل جذبا & 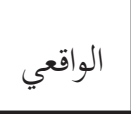 & \\
\hline \multirow{5}{*}{ جليًا } & قليلة & متوسطة & 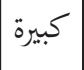 & كبيرة & الموقف وفقراته & & \\
\hline & & & & & \multicolumn{2}{|c|}{ 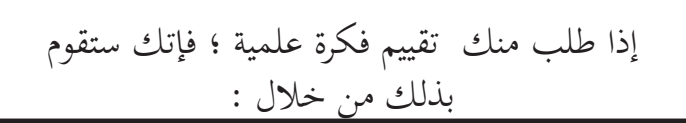 } & \multirow{6}{*}{11} \\
\hline & & & & & مقارنة الفكرة مع أفكار مألوفة مشابكة لها & 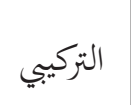 & \\
\hline & & & & & توافق الفكرة مع القيم والمثل الاجتماعية . & 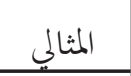 & \\
\hline & & & & & تقييم مدى الفائدة الاقتصادية للفكرة . & 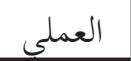 & \\
\hline & & & & & تقييم جميع الأجزاء الملكونة للفكرة . & التحليلي & \\
\hline & & & & & إمكانية تطبيق الفكرة في الواقع العملى . & & \\
\hline
\end{tabular}

المجلد ( 2 ) - العدد (2021 ) ديسمبر 2021م

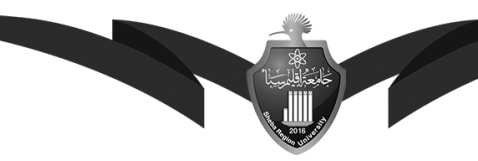




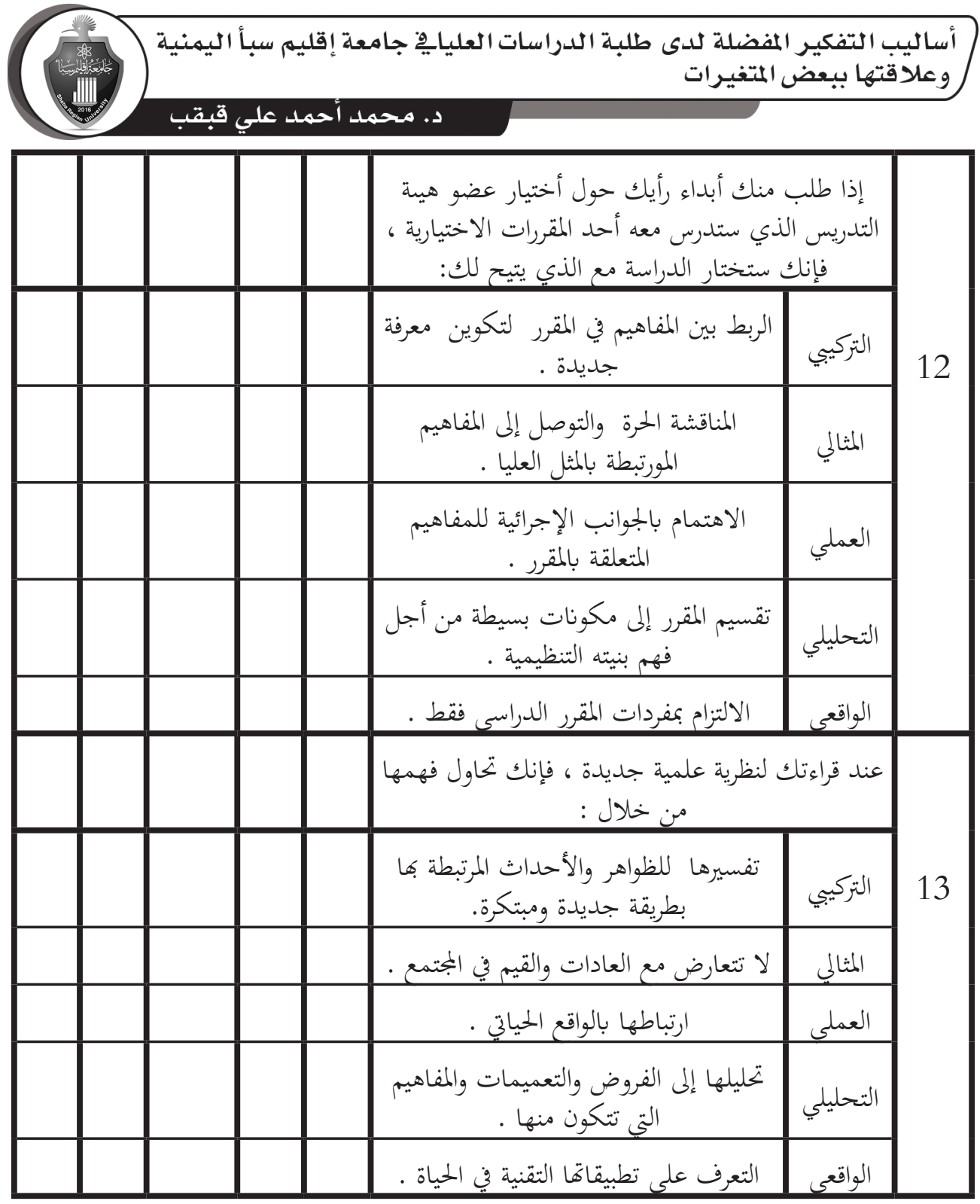

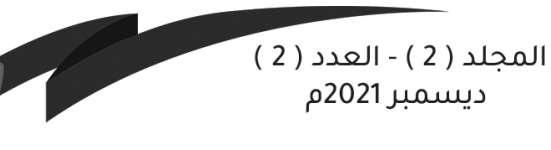




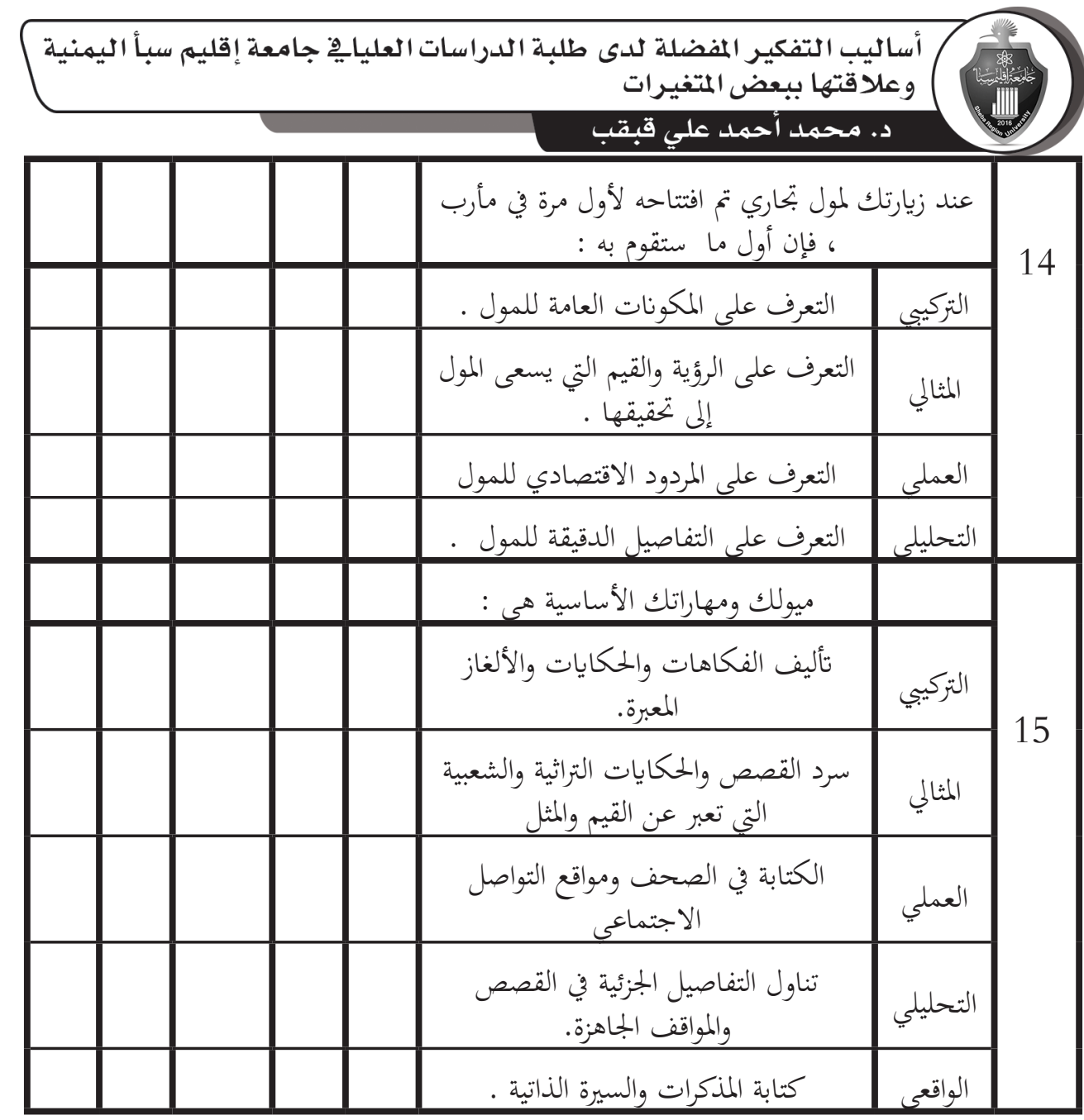

المجلد ( 2 ) - العدد ( 2 ) ديسمبر 2021م

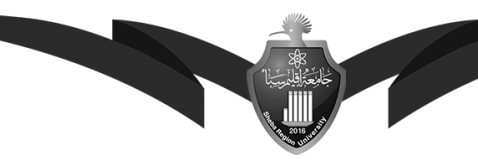

